\title{
Components of the antigen processing and presentation pathway revealed by gene expression microarray analysis following B cell antigen receptor $(B C R)$ stimulation
}

\author{
Jamie A Lee ${ }^{\dagger 1}$, Robert S Sinkovits ${ }^{\dagger 3}$, Dennis Mock ${ }^{\dagger 3}$, Eva L Rab ${ }^{1}$, Jennifer Cai ${ }^{1}$, \\ Peng Yang ${ }^{1}$, Brian Saunders ${ }^{3}$, Robert C Hsueh ${ }^{2}$, Sangdun Choi ${ }^{5}$, \\ Shankar Subramaniam ${ }^{3,4}$, Richard H Scheuermann*1,3 and in collaboration \\ with the Alliance for Cellular Signaling
}

Address: ${ }^{1}$ Department of Pathology, Laboratory of Molecular Pathology, University of Texas Southwestern Medical Center, Dallas, Texas 75390 , USA, ${ }^{2}$ Department of Pharmacology, University of Texas Southwestern Medical Center, Dallas, Texas 75390, USA, ${ }^{3}$ San Diego Supercomputer Center, University of California, San Diego, California 92122, USA, ${ }^{4}$ Department of Bioengineering, University of California, San Diego, California 92122, USA and ${ }^{5}$ Division of Biology, California Institute of Technology, Pasadena, CA, USA

Email: Jamie A Lee - Jamie.lee@utsouthwestern.edu; Robert S Sinkovits - sinkovit@sdsc.edu; Dennis Mock - dmock@sdsc.edu; Eva L Rab - eva.rab@utsouthwestern.edu; Jennifer Cai - Jennifer.cai@utsouthwestern.edu; Peng Yang - YangPeng@PRAIntl.com; Brian Saunders - saunders@sdsc.edu; Robert C Hsueh - Robert.hsueh@utsouthwestern.edu; Sangdun Choi - schoi@caltech.edu; Shankar Subramaniam - shankar@sdsc.edu; Richard H Scheuermann* - scheuerm@utsw.swmed.edu; in collaboration with the Alliance for Cellular Signaling - webmaster@signaling-gateway.org

* Corresponding author †Equal contributors

\section{Published: 02 May 2006}

BMC Bioinformatics 2006, 7:237 doi:10.1/86/147/-2105-7-237
Received: 21 September 2005

Accepted: 02 May 2006

This article is available from: http://www.biomedcentral.com/147I-2105/7/237

(C) 2006 Lee et al; licensee BioMed Central Ltd.

This is an Open Access article distributed under the terms of the Creative Commons Attribution License (http://creativecommons.org/licenses/by/2.0), which permits unrestricted use, distribution, and reproduction in any medium, provided the original work is properly cited.

\begin{abstract}
Background: Activation of naïve B lymphocytes by extracellular ligands, e.g. antigen, lipopolysaccharide (LPS) and CD40 ligand, induces a combination of common and ligand-specific phenotypic changes through complex signal transduction pathways. For example, although all three of these ligands induce proliferation, only stimulation through the $B$ cell antigen receptor (BCR) induces apoptosis in resting splenic $B$ cells. In order to define the common and unique biological responses to ligand stimulation, we compared the gene expression changes induced in normal primary B cells by a panel of ligands using CDNA microarrays and a statistical approach, CLASSIFI (Cluster Assignment for Biological Inference), which identifies significant co-clustering of genes with similar Gene Ontology ${ }^{\mathrm{TM}}$ annotation.

Results: CLASSIFI analysis revealed an overrepresentation of genes involved in ion and vesicle transport, including multiple components of the proton pump, in the BCR-specific gene cluster, suggesting that activation of antigen processing and presentation pathways is a major biological response to antigen receptor stimulation. Proton pump components that were not included in the initial microarray data set were also upregulated in response to BCR stimulation in follow up experiments. MHC Class II expression was found to be maintained specifically in response to BCR stimulation. Furthermore, ligand-specific internalization of the BCR, a first step in B cell antigen processing and presentation, was demonstrated.

Conclusion: These observations provide experimental validation of the computational approach implemented in CLASSIFI, demonstrating that CLASSIFI-based gene expression cluster analysis is an effective data mining tool to identify biological processes that correlate with the experimental conditional variables. Furthermore, this analysis has identified at least thirty-eight candidate components of the B cell antigen processing and presentation pathway and sets the stage for future studies focused on a better understanding of the components involved in and unique to $B$ cell antigen processing and presentation.
\end{abstract}




\section{Background}

Naïve mature B cells in peripheral lymphoid organs respond to a variety of extracellular signals through the activation of signal transduction pathways initiated by the $\mathrm{B}$ cell antigen, pattern-recognition, cytokine and chemokine receptors. $\mathrm{B}$ cell responses to signaling depend on the combination of ligands present, and include activation, proliferation, migration, differentiation, isotype class switching, somatic hypermutation, anergy, and apoptosis $[1,2]$. Once activated, B cells can also serve as antigen presenting cells that preferentially present antigens recognized by their specific BCR. In contrast, dendritic cells and macrophages present varied antigens that are acquired less specifically through phagocytosis, macropinocytosis and receptor-mediated endocytosis via pattern-recognition receptors such as the mannose receptor.

BCR-specific antigen processing and presentation is initiated by BCR-mediated signal transduction triggered by antigenic stimulation $[3,4]$. Antigen is then internalized by receptor-mediated endocytosis and trafficked through endosomes for acidification and fusion with lysosomes containing $\mathrm{pH}$-sensitive hydrolytic enzymes for antigen processing. Endolysosomes containing processed antigenic peptides fuse with Golgi-derived vesicles containing MHC class II molecules assembled with invariant chain (Ii). The CLIP fragment of Ii bound in the cleft of the class II a $\beta$ dimer is replaced by antigen-derived peptides and the complex trafficked to the cell surface through vesicle secretory pathways.

It is well known that B cell antigen processing and presentation mediated through the BCR far exceeds the efficiency of presentation of the same antigen by macrophages or dendritic cells [5]. The mechanism giving rise to this increased efficiency has not been fully determined but appears to be a unique aspect of BCR-mediated antigen capture and processing as opposed to changes in the basic antigen processing and presentation machinery [6]. One mechanism that may contribute to efficiency is accelerated trafficking of BCR/antigen complexes to Class II containing vesicles inside the cell [7]. However, the molecular mediators of this vesicle trafficking, especially those components uniquely involved in the highly efficient $\mathrm{B}$ cell antigen processing and presentation pathway, have remained largely unknown.

We analyzed a B cell microarray dataset comparing the responses of normal splenic B cells to 32 individual ligands. This study was designed to determine functionally important input signals to contribute to the understanding of normal B cell biology and differs from existing B cell microarray studies which largely compare normal B cells to B cell lymphomas to identify tumor-specific gene expression changes. By combining this gene expression microarray analysis with bioinformatics analyses and functional assays, we have identified a set of specific genes that appear to be involved in BCR-mediated antigen capture, vesicle function and vesicle trafficking during B cell antigen processing and presentation. These data provide a foundation for the molecular characterization of this important immunological process.

\section{Results \\ Microarray analysis of ligand-treated B lymphocytes}

Purified B lymphocytes were treated in culture with 32 different ligands over a timecourse of $30 \mathrm{~min}, 1 \mathrm{hr}, 2 \mathrm{hr}$, and $4 \mathrm{hr}$. A detailed description of the data set has been published [8]. Following filtering, normalization and SAM analysis, genes that were differentially expressed by each ligand in comparison with time-matched, untreated controls were identified. Of the 32 ligands, CD40L, LPS, and AIG caused the most gene expression changes, especially at the $4 \mathrm{hr}$ timepoint (Figure 1B). Further analysis focuses on these three immunologically-important ligands. Categorical values of $1,-1$, and 0 (representing significantly upregulated, downregulated, or unchanged) were used to group genes together based on their expression response patterns (Table 1). Genes not differentially expressed under at least one treatment condition were omitted from further analysis. Based on 3 ligand combinations and a possibility of 3 outcomes for each ligand $(1,-1,0)$, there are a possible $3^{3}$ or 27 gene clusters, with the $(0,0,0)$ outcome excluded since only genes that were differentially expressed under at least one treatment condition were selected (26 possible gene clusters). In our dataset, we only observe 19 of these possible 26 . A variety of different expression patterns were observed. For example, Gene Cluster \# 1 contains genes that are upregulated by all three ligands, whereas Gene Cluster \# 14 contains genes that are only upregulated in response to LPS.

CLASSIFI analysis links gene clusters to cellular physiology Microarray expression data can be full of experimental and biological noise, and many microarray probes are not well characterized. We developed a gene cluster classification method that circumvents these limitations and links biological function with gene expression patterns derived from microarray experiments. This method, termed CLASSIFI, uses Gene Ontology ${ }^{\mathrm{TM}}$ annotation to identify significant co-clustering of genes with similar biological properties, based on the postulate that genes involved in the same biological process would be coordinately expressed.

CLASSIFI utilizes the gene description database developed by the Gene Ontology ${ }^{\mathrm{TM}}$ (GO) Consortium [9] to reveal co-clustering of genes with similar biological properties. The GO annotates gene products with GO terms based upon their molecular function, biological process, and 
A

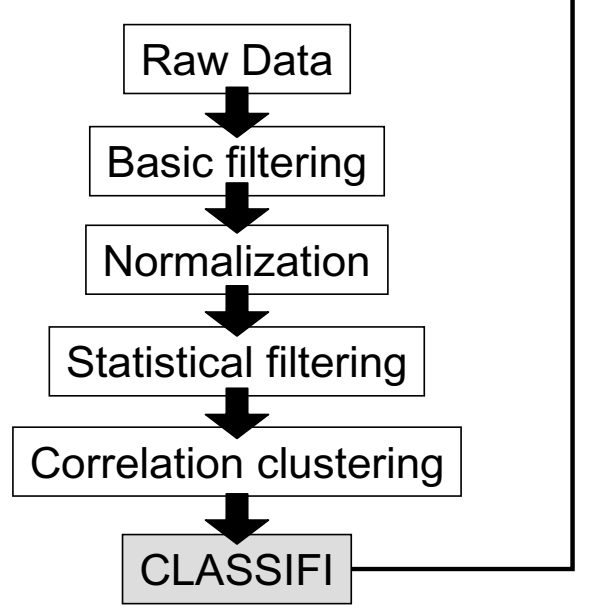

B

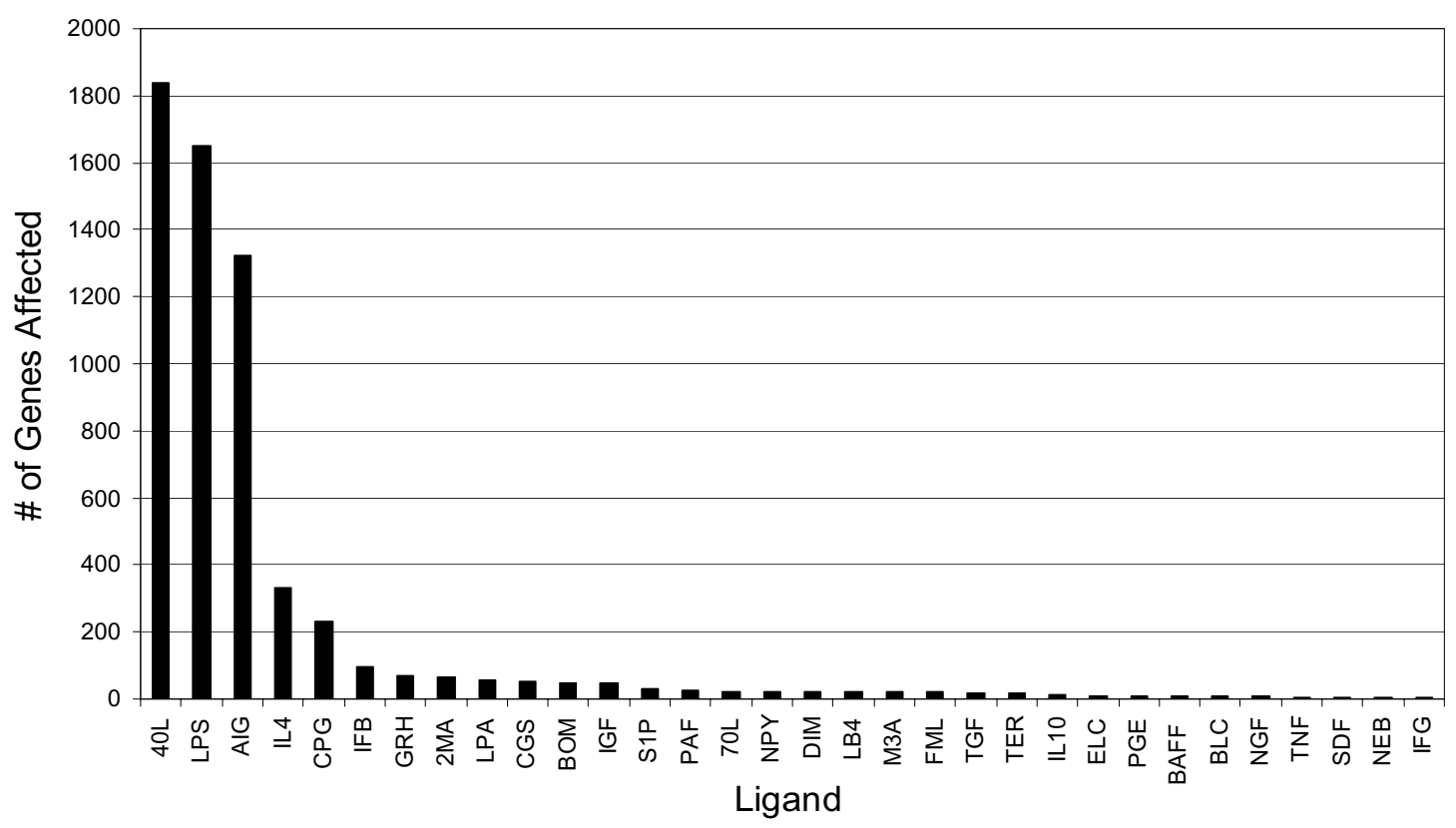

Figure I

Experimental methodology and analysis of microarray data. (A) Schematic of steps performed during microarray data processing. Gray boxes indicate steps performed as part of the CLASSIFI component of the analysis. See text for details. (B) The number of genes whose expression was significantly changed at the $4 \mathrm{hr}$ timepoint as determined by SAM is shown for each of 32 ligands. Abbreviations and descriptions for each ligand can be found at [22]. 40L = CD40L (anti-CD40), LPS = Lipopolysaccharide, and AIG = anti-lgM. 
Table I: Clustering and CLASSIFI results for data from 3 ligands

\begin{tabular}{|c|c|c|c|c|c|c|c|c|c|c|c|c|}
\hline GO ID & $g$ & $f$ & c & $\mathrm{n}$ & expt & prob & GO type & GO term & Cluster ID & anti-CD40 & LPS & AIG \\
\hline GO:0005634 & 2490 & 254 & 380 & 64 & 38.76 & 8.7IE-06 & $\mathrm{CC}$ & Nucleus & I & I & I & 1 \\
\hline GO:0009058 & 2490 & $|4|$ & 180 & 25 & 10.19 & I.36E-05 & $\mathrm{BP}$ & biosynthesis & 2 & 1 & I & \\
\hline GO:0008372 & 2490 & 1409 & I & I & 0.566 & $5.66 \mathrm{E}-0 \mathrm{I}$ & $\mathrm{CC}$ & CC unknown & 3 & I & -1 & -1 \\
\hline GO:0046072 & 2490 & 2 & 160 & 2 & 0.129 & 4. $10 \mathrm{E}-03$ & $\mathrm{BP}$ & dTDP metabolism & 4 & 1 & & I \\
\hline GO:0009605 & 2490 & 30 & 3 & 2 & 0.036 & 4. $18 \mathrm{E}-04$ & $\mathrm{BP}$ & response to external stimulus & 5 & 1 & & -1 \\
\hline GO:0016655 & 2490 & 14 & 331 & $\mathrm{II}$ & 1.861 & 4.94E-08 & MF & $\begin{array}{l}\text { oxidoreductase activity, acting on } \\
\text { NADH }\end{array}$ & 6 & 1 & & \\
\hline GO:0005773 & 2490 & 12 & 11 & 4 & 0.053 & I.00E-07 & $\mathrm{CC}$ & Vacuole & 7 & -1 & -1 & I \\
\hline GO:0003779 & 2490 & 15 & 277 & 9 & 1.669 & $6.30 \mathrm{E}-06$ & MF & actin binding & 8 & -1 & -1 & -1 \\
\hline GO:0016758 & 2490 & 6 & 245 & 4 & 0.59 & I.I7E-03 & MF & $\begin{array}{l}\text { Transferase activity, transferring } \\
\text { hexosyl groups }\end{array}$ & 9 & -1 & -1 & \\
\hline GO:00064I7 & 2490 & 2 & 4 & 1 & 0.003 & $3.21 \mathrm{IE}-03$ & BP & regulation of protein biosynthesis & 10 & -1 & & I \\
\hline GO:0008372 & 2490 & 1409 & 41 & 32 & 23.2 & $3.30 \mathrm{E}-03$ & $\mathrm{CC}$ & CC unknown & 11 & -1 & & -1 \\
\hline GO:0008047 & 2490 & 10 & 160 & 3 & 0.643 & $2.23 \mathrm{E}-02$ & MF & enzyme activator activity & 12 & -1 & & \\
\hline GO:0006397 & 2490 & 19 & 56 & 4 & 0.427 & $6.92 \mathrm{E}-04$ & $\mathrm{BP}$ & mRNA processing & 13 & & 1 & 1 \\
\hline GO:0005576 & 2490 & 156 & 183 & 33 & 11.47 & $7.28 \mathrm{E}-09$ & $\mathrm{CC}$ & extracellular & 14 & & 1 & \\
\hline GO:0046916 & 2490 & I & 4 & 1 & 0.002 & I.6IE-03 & $\mathrm{BP}$ & transition metal ion homeostasis & 15 & & -1 & $\mathrm{I}$ \\
\hline GO:000393I & 2490 & 3 & 38 & 2 & 0.046 & $6.74 \mathrm{E}-04$ & MF & $\begin{array}{l}\text { Rho small monomeric GTPase } \\
\text { activity }\end{array}$ & 16 & & -1 & -1 \\
\hline GO:0004032 & 2490 & 3 & 188 & 3 & 0.227 & $4.24 \mathrm{E}-04$ & MF & aldehyde reductase activity & 17 & & -1 & \\
\hline GO:00I5672 & 2490 & 10 & 191 & 7 & 0.767 & $1.38 \mathrm{E}-06$ & $\mathrm{BP}$ & $\begin{array}{l}\text { monovalent inorganic cation } \\
\text { transport }\end{array}$ & 18 & & & $\mathrm{I}$ \\
\hline GO:0016892 & 2490 & 3 & 50 & 2 & 0.06 & $1.17 \mathrm{E}-03$ & MF & $\begin{array}{l}\text { endoribonuclease activity, } \\
\text { producing other than }\end{array}$ & 19 & & & -1 \\
\hline
\end{tabular}

Gene clusters (Cluster ID I-19) resulting from categorical clustering of processed data from B cells stimulated with anti-CD40, LPS, and AIG. "I" = upregulated, "-I" = downregulated, and blank = no significant change. Following CLASSIFI analysis, the GO term giving rise to the lowest probability in each gene cluster is indicated. GO ID = a unique Gene Ontology identifier assigned to a GO term that corresponds to a defined molecular function (MF), biological process (BP), or cellular component (CC). $g=$ number of probes in the data set, $f=$ number of probes with associated $G O$ ID in the data set, $c=$ number of probes in the gene cluster, $n=$ number of probes with associated $G O$ ID in the gene cluster. Expt $=$ the expected number of occurrences of a given GO ID in a given cluster of size $(n)$ based on a random distribution. Prob $=$ the probability that the GO ID cocluster pattern has occurred by chance.

cellular component. These descriptive terms are structured in a directed acyclic graph of parent-child relationships, allowing a term to have multiple parents [10,11]. GO gene annotation has also been used by other groups as a tool for identifying biological processes relevant to gene expression profiling experiments [11-13].

CLASSIFI measures the probability of co-clustering for every gene ontology term designated to every gene in each gene cluster. Gene expression data clustering and gene cluster membership assignment generates the CLASSIFI input file (See Additional file 1). CLASSIFI captures all of the GO terms annotated to every probe and then calculates the probability of chance co-clustering of GO terms. The final CLASSIFI output is a list of every GO term, ranked within each gene cluster from lowest to highest probability (See Additional file 2).

The filtered data set contained 2545 probes, which led to the calculation of 5036 probabilities (See Additional file 3 ). The GO term with the lowest probability for each gene cluster is shown in Table 1. A significance cutoff of $1 \times 10^{-}$ ${ }^{5}$ was established using a Bonferroni correction with an alpha of 0.05 and an $n$ of 5036 (see [14] and references therein). Six gene clusters give rise to GO terms with significant probabilities: Gene Cluster \#1, 6, 7, 8, 14, and 18 . Gene clusters identified by CLASSIFI to give significant probabilities exhibit predictable expression patterns that could be explained biologically, including gene clusters characterized by ligand-specific expression induction. Experimental noise may contribute to gene clusters with insignificant probabilities that show unusual expression patterns.

CLASSIFI results for some gene clusters are expected based on our current understanding of B cell physiology. For example, the GO term giving the lowest probability in Gene Cluster \# 1 is "nucleus". This gene cluster represents genes which are upregulated in response to all three ligands: AIG, CD40L, and LPS, and includes genes involved in transcription, replication and RNA processing. All three of these ligands induce cellular activation $[1,2,15]$ and proliferation (data not shown), so we would expect these kinds of nuclear genes to be highly expressed in B cells stimulated with all three ligands. The GO term giving the lowest probability in Gene Cluster \#6 is "oxidoreductase 
activity, acting on NADH or NADPH". It has recently been shown that stimulation through CD40 and other TNF family members results in the production of reactive oxygen species through NADPH [16]. Importantly, many of the GO terms giving the low probabilities in a given gene cluster are functionally related, e.g. monovalent inorganic ion transport, ion transport, transporter activity, and cation transport in Gene Cluster \#18 (Table 2).

\section{Experimental validation of CLASSIFI-derived biological predictions}

CLASSIFI analysis should be viewed as a hypothesis-generating tool. While the statistical analysis is compelling, predictions that derive from the hypotheses should be verified experimentally. We were particularly interested in the AIG-specific Gene Cluster \#18 because these genes represent biological processes that are unique to antigenic stimulation rather than the general activation responses induced by all three ligands. The GO term giving the lowest probability in Gene Cluster \#18 is "monovalent inor- ganic cation transport" (GO:0015672). An examination of the genes annotated with this GO term revealed multiple components of the vacuolar ATPase $\mathrm{H}+$ pump (Table $3)$. Since stimulation through the BCR induces internalization of the receptor-antigen complex and trafficking through the endocytic system, "monovalent inorganic cation transport" could reflect the acidification of vesicles as they progress from endosomes to lysosomes during endocytosis. This AIG-specific cluster also contained an overrepresentation of genes involved in general "transporter activity" (GO:0005215), which includes genes like Rab9, sorting nexin 5 (Snx5) and N-ethylmaleimide sensitive fusion protein attachment protein alpha (Napa) that are involved in endosome trafficking and vesicle fusion. These observations led us to consider the hypothesis that AIG might induce the expression of various components of the endocytic and vesicle transport pathways in a manner that is independent of its effects on the general metabolic activation and proliferation of B cells, and that this

Table 2: Excerpt of CLASSIFI results for six gene clusters giving significant probabilities

\begin{tabular}{|c|c|c|c|c|c|c|}
\hline GO ID & $f$ & $\mathrm{n}$ & prob & GO type & GO term & Cluster ID \\
\hline GO:0005634 & 254 & 64 & 8.7IE-06 & $\mathrm{CC}$ & nucleus & 1 \\
\hline GO:0005635 & 13 & 9 & I.66E-05 & $\mathrm{CC}$ & nuclear membrane & I \\
\hline GO:00064I2 & 94 & 30 & 2.75E-05 & $\mathrm{BP}$ & protein biosynthesis & 1 \\
\hline GO:0009059 & 94 & 30 & $2.75 \mathrm{E}-05$ & $\mathrm{BP}$ & macromolecule biosynthesis & 1 \\
\hline GO:0003743 & 20 & 10 & $2.68 \mathrm{E}-04$ & MF & translation initiation factor activity & 1 \\
\hline GO:0016655 & 14 & 11 & 4.94E-08 & MF & $\begin{array}{l}\text { oxidoreductase activity, acting on NADH or NADPH, quinone or } \\
\text { similar compound as acceptor }\end{array}$ & 6 \\
\hline GO:0008137 & 14 & 11 & 4.94E-08 & MF & NADH dehydrogenase (ubiquinone) activity & 6 \\
\hline GO:00I508I & 14 & 11 & 4.94E-08 & MF & sodium ion transporter activity & 6 \\
\hline GO:001665I & 16 & 11 & 4.6IE-07 & MF & oxidoreductase activity, acting on NADH or NADPH & 6 \\
\hline GO:0046873 & 16 & 11 & 4.6IE-07 & MF & metal ion transporter activity & 6 \\
\hline GO:0005773 & 12 & 4 & I.00E-07 & $\mathrm{CC}$ & vacuole & 7 \\
\hline GO:0016787 & 163 & 6 & $2.52 \mathrm{E}-05$ & MF & hydrolase activity & 7 \\
\hline GO:0005624 & 15 & 3 & $2.84 \mathrm{E}-05$ & $\mathrm{CC}$ & membrane fraction & 7 \\
\hline GO:0000267 & 18 & 3 & 5.05E-05 & $\mathrm{CC}$ & cell fraction & 7 \\
\hline GO:0015991 & 3 & 2 & $5.3 \mathrm{IE}-05$ & $\mathrm{BP}$ & ATP hydrolysis coupled proton transport & 7 \\
\hline GO:0003779 & 15 & 9 & $6.30 \mathrm{E}-06$ & MF & actin binding & 8 \\
\hline GO:0008092 & 22 & 9 & 3.08E-04 & MF & cytoskeletal protein binding & 8 \\
\hline GO:0003785 & 6 & 4 & I.88E-03 & MF & actin monomer binding & 8 \\
\hline GO:0006357 & 10 & 5 & $2.58 \mathrm{E}-03$ & $\mathrm{BP}$ & regulation of transcription from Pol II promoter & 8 \\
\hline GO:0006355 & 79 & 17 & 4.85E-03 & $\mathrm{BP}$ & regulation of transcription, DNA-dependent & 8 \\
\hline GO:0005576 & 156 & 33 & 7.28E-09 & $\mathrm{CC}$ & extracellular & 14 \\
\hline GO:0005578 & 5 & 4 & I.33E-04 & $\mathrm{CC}$ & extracellular matrix & 14 \\
\hline GO:000487I & 50 & 11 & 7.39E-04 & MF & signal transducer activity & 14 \\
\hline GO:0004888 & 7 & 4 & 8.29E-04 & MF & transmembrane receptor activity & 14 \\
\hline GO:0007I66 & 25 & 7 & I.59E-03 & $\mathrm{BP}$ & cell surface receptor linked signal transduction & 14 \\
\hline GO:0015672 & 10 & 7 & I.38E-06 & $\mathrm{BP}$ & monovalent inorganic cation transport & 18 \\
\hline GO:00068II & 23 & 10 & 2.65E-06 & $\mathrm{BP}$ & ion transport & 18 \\
\hline GO:00052I5 & 122 & 24 & $9.10 \mathrm{E}-06$ & MF & transporter activity & 18 \\
\hline GO:00068I2 & 18 & 8 & $2.33 \mathrm{E}-05$ & $\mathrm{BP}$ & cation transport & 18 \\
\hline GO:0006754 & 4 & 4 & $3.36 \mathrm{E}-05$ & $\mathrm{BP}$ & ATP biosynthesis & 18 \\
\hline
\end{tabular}

The five GO IDs giving the lowest probability are listed for each of six gene clusters giving significant probabilities in Table I. GO ID = a unique Gene Ontology identifier that corresponds to a defined molecular function, biological process, or cellular component $(G O$ name). $f=$ number of probes with the associated GO ID in the data set, $n=$ number of probes with the associated GO ID in the gene cluster. prob $=$ the probability that the GO ID co-cluster pattern has occurred by chance. 
Table 3: Genes annotated with transport-related GO terms from Gene Cluster \#। 8

\begin{tabular}{|c|c|c|}
\hline GO ID & Probe ID & Gene Name \\
\hline GO:0015672 & C530010121 & ATPase, $\mathrm{H}+$ transporting, $\mathrm{V} 0$ subunit $\mathrm{B}$ \\
\hline GO:0015672 & $2310069 \mathrm{HI} 4$ & ATPase, $\mathrm{H}+$ transporting, $\mathrm{VI}$ subunit $\mathrm{G}$ isoform I \\
\hline GO:0015672 & $5730403 E 06$ & SIMILAR TO ATPASE, H+ TRANSPORTING, LYSOSOMAL \\
\hline GO:00068II & 2810002005 & sideroflexin I \\
\hline GO:00068II & $1810048 \mathrm{H} 22$ & arsA (bacterial) arsenite transporter, ATP-binding, homolog I \\
\hline GO:00068II & $23|002| \mathrm{D} \mid 4$ & chloride channel 7 \\
\hline GO:00052I5 & I8I00IIE08 & MICROSOMAL SIGNAL PEPTIDASE 23 KDA SUBUNIT (EC 3.4.-.-) \\
\hline GO:00052I 5 & $2810433 C 04$ & translocase of inner mitochondrial membrane 9 homolog (yeast) \\
\hline GO:00052I5 & $1500039 \mathrm{~N} 14$ & $\mathrm{~N}$-ethylmaleimide sensitive fusion protein attachment protein alpha \\
\hline GO:00052I5 & $2210039 \mathrm{GII}$ & fatty acid binding protein 5 , epidermal \\
\hline GO:00052I5 & $5430437 \mathrm{~K} 12$ & zinc finger protein 295 \\
\hline GO:00052I5 & $1810057 M 21$ & thioredoxin reductase I \\
\hline GO:00052I5 & $2310004 \mathrm{LI} 3$ & translocase of inner mitochondrial membrane 9 homolog (yeast) \\
\hline GO:00052I 5 & $2610025 \mathrm{H} 03$ & fatty acid binding protein 5 , epidermal \\
\hline GO:00052I5 & $54304 \mid 3 F 24$ & RAB9, member RAS oncogene family \\
\hline GO:00052I5 & $58304 \mid 7 j 06$ & 24-dehydrocholesterol reductase \\
\hline GO:00052I5 & $0910001 N 05$ & sorting nexin 5 \\
\hline GO:00052I5 & $2410046 \mathrm{~L} 22$ & FK506 binding protein la \\
\hline GO:00052I5 & $2010015 D 08$ & vacuolar protein sorting 29 (S. pombe) \\
\hline GO:0005215 & $3010014 K 12$ & $\mathrm{~N}$-ethylmaleimide sensitive fusion protein attachment protein alpha \\
\hline
\end{tabular}

List of characterized genes detected using specific cDNA probes (Probe ID) found in Gene Cluster \#18 that are associated with GO terms "monovalent inorganic ion transport" (GO:00I5672), "ion transport" (GO:00068II), and "transporter activity" (GO:00052I5). N.B. GO:00I5672 is a child of GO:00068I I, which is a child of GO:00052I5 in the GO hierarchy.

might be part of a B cell-specific antigen processing and presentation function.

To ensure that the genes identified through the CLASSIFI analysis were meaningful, we first sought to verify their differential expression patterns. The microarray expression pattern of nine probes recognizing "transporter activity" genes in unstimulated and ligand-stimulated samples were evaluated (Figure 2A). In every case, expression of these genes was similar in all treatment conditions at 0.5 and $1 \mathrm{hr}$, but was higher in the AIG-treated samples at 2 $\mathrm{hr}$ and $4 \mathrm{hr}$. Examples in which the same gene is represented by two different probes show closely similar expression patterns, indicating the high quality of this microarray data set. To verify the ligand-specificity of expression, RT-PCR was used to examine the expression of a subset of these genes in independently-generated samples. Again, AIG induced enhanced expression of each of these genes compared to LPS and anti-CD40 (Figure 2B). RT-PCR results consistently confirm microarray expression data in this data set [8].

CLASSIFI analysis is based on the postulate that genes involved in the same biological process are coordinately expressed. Thus, one prediction of this analysis is that other genes involved in the same biological process that were not included in the microarray probe data set would show the same expression pattern. We evaluated 4 such genes that encode ATPase $\mathrm{H}+$ pump complex subunits by RT-PCR. All of these genes demonstrated a preferential upregulation in response to AIG (Figure 2C). These data not only provide experimental validation of the CLASSIFI approach to microarray data analysis, but also further supports the hypothesis that AIG induces vesicle processing and transport as a biological process.

In order to further test predictions that follow from the CLASSIFI analysis we sought to determine if the process of endocytosis is activated in a ligand/receptor-specific manner. An internalization assay was performed in which the BCR is fluorescently labeled with a non-stimulating antiIgM-FITC antibody prior to AIG treatment. After allowing time for internalization, the cells are subjected to an acid wash to remove surface-bound label. Label that has been internalized is protected from the acid wash and can therefore be detected using flow cytometry. Using this method, we found that BCR internalization (arrow, Figure 3D) occurs with AIG stimulation, but not CD40L or LPS stimulation in WEHI-231 cells (Figure 3A, G). Substantial internalization was found as early as 15 minutes poststimulation and continued past 4 hours. Using fluorescence microscopy, internalized BCR can be seen in AIGtreated cells by 10 minutes. No internalization of the BCR is detected with anti-CD40 or LPS treatment (Figure 3J). Ligand-specific internalization of the BCR was also detected in primary B cells (data not shown).

To test whether receptor internalization following AIG stimulation is specific to the BCR and not other cell surface receptors, we performed internalization assays in 

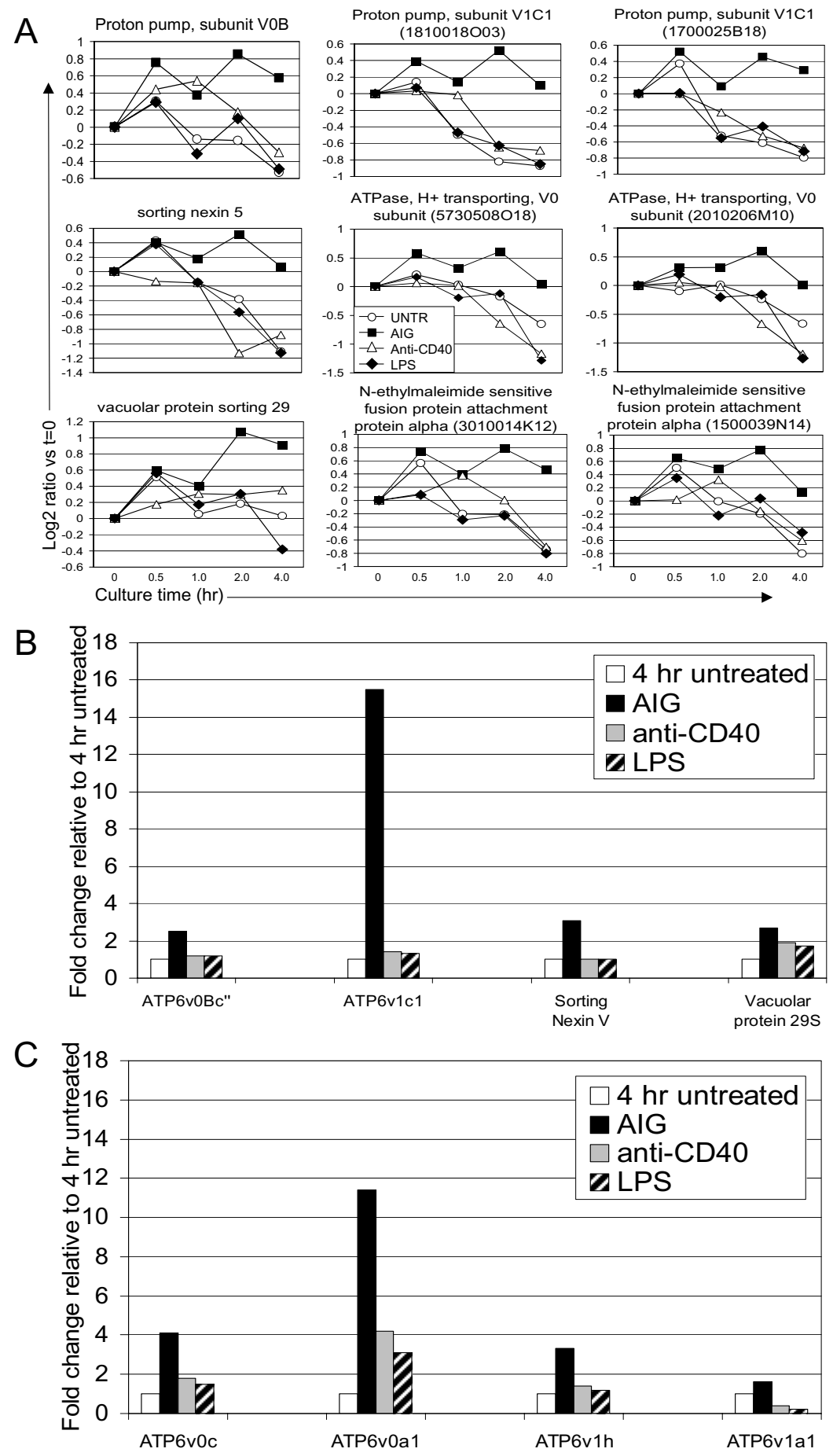

\section{Figure 2}

Expression data from select intracellular transport-related genes. (A) Microarray results for expression patterns of several genes over a timecourse of 0.5 to $4 \mathrm{hr}$. The $\log _{2}(\mathrm{Cy} 5 / \mathrm{Cy} 3)$ values were compared to $0 \mathrm{hr}$ untreated samples $(\mathrm{t}=0)$. Three examples of genes represented by two different probes (probe Ids in parentheses) are shown in the two right columns. (B) Real-time RT-PCR analysis of four intracellular transport-related genes at 4 hours of stimulation that were included in the microarray data set. Data were normalized to mouse I8S rRNA as a reference and compared to untreated samples.

ATP6v0bc" and ATP6vlcl, $n=2$. Sorting nexin $V$ and Vacuolar protein $29 S, n=1$. (C) Real-time RT-PCR analysis of 4 intracellular transport-related genes at 4 hours of stimulation that were not included in the microarray data set. 

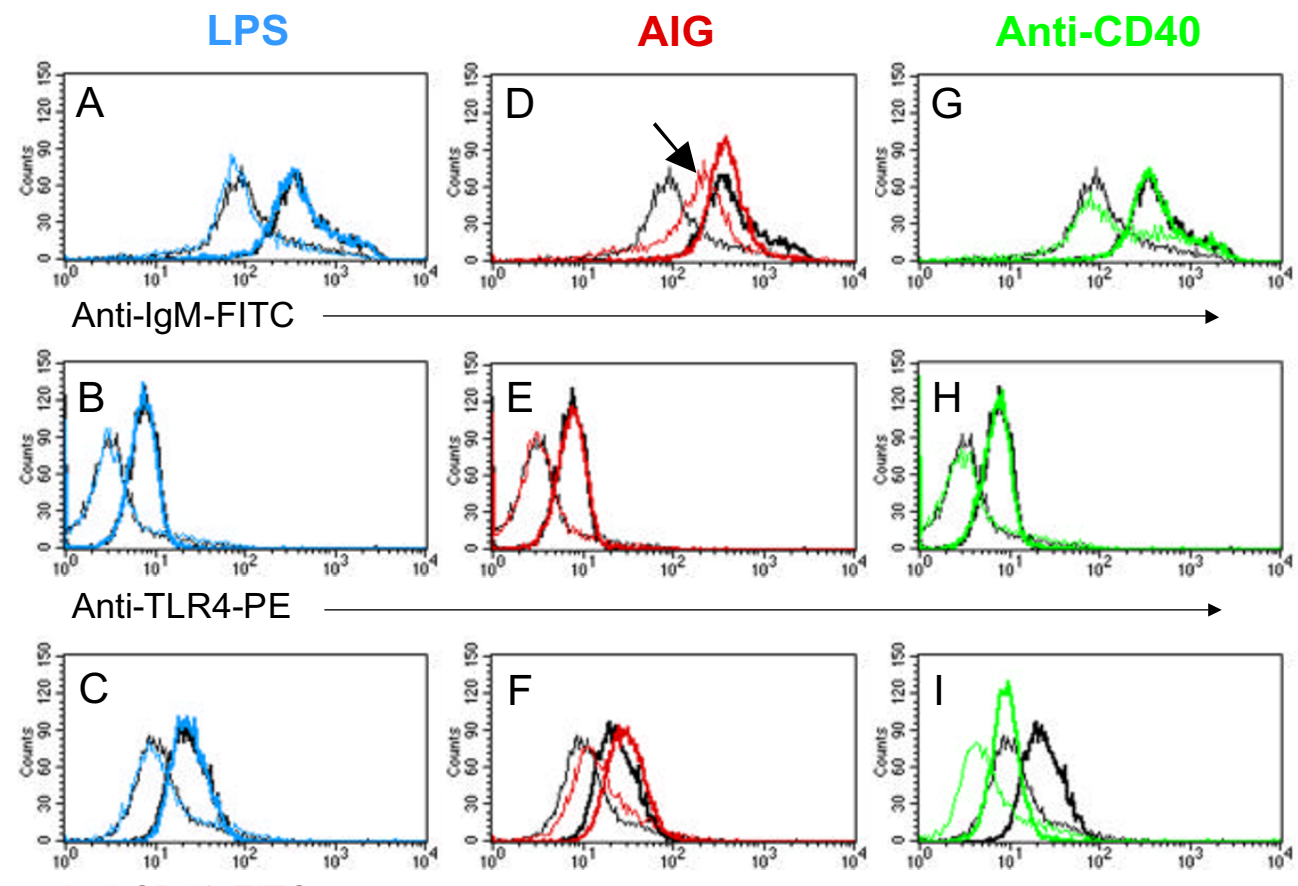

Anti-CD40-FITC
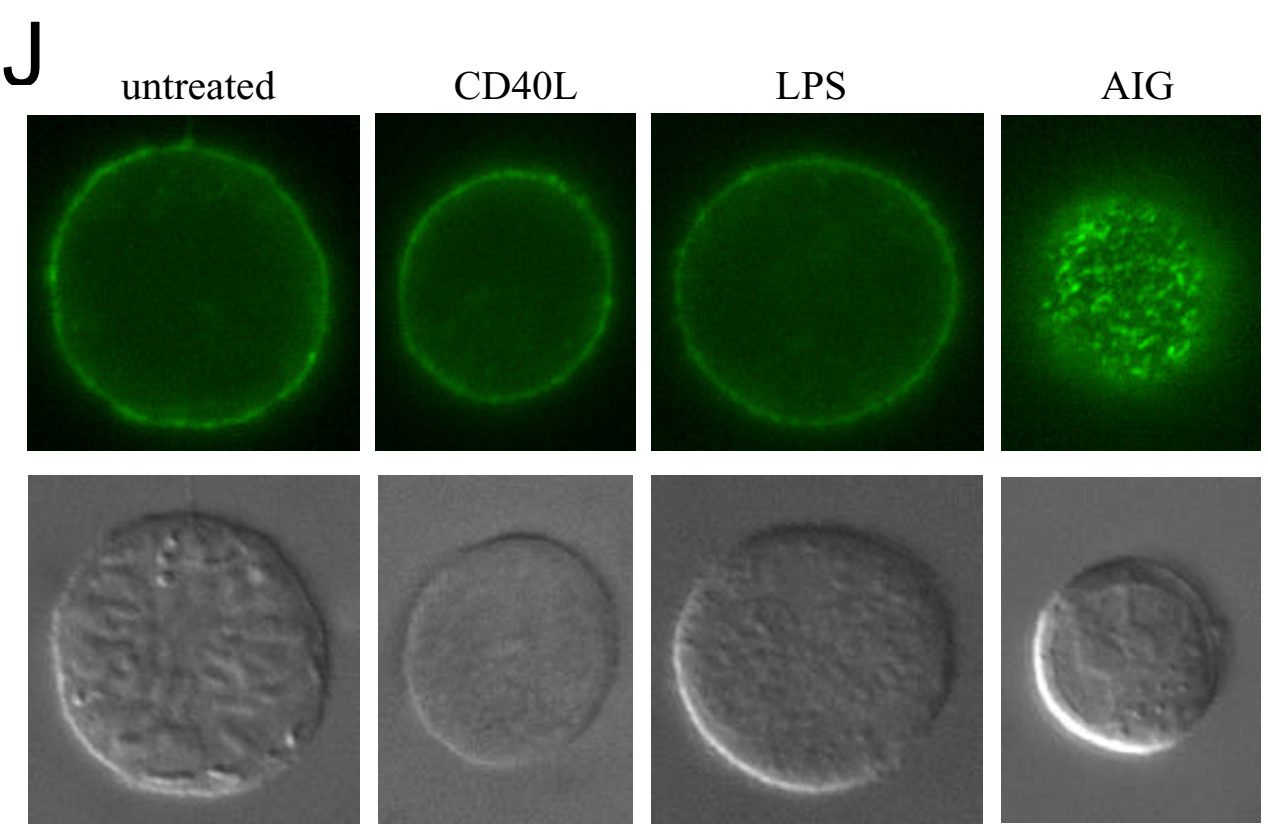

\section{Figure 3}

Internalization of cell surface receptors in WEHI-23 I. (A-I) Assay for internalization of BCR, CD40, and TLR4 was performed using WEHI-23 I cells. Data from I hr stimulations are shown. Line thickness represents treatment of cells following labeling of receptor where thin $=$ acid treated samples and thick $=$ no acid treatment. Black $=$ unstimulated, blue $=$ LPS stimulated, red = AIG stimulated, green = anti-CD40 stimulated. Arrow denotes histogram of acid-treated cells in which labeled $B C R$ is protected from the effects of acid treatment with AIG stimulation. () Localization of the BCR by fluorescence microscopy. BCR are labeled with a non-stimulating FITC-conjugated monoclonal anti-IgM antibody (green) and treated for 10 minutes as indicated. DIC images are shown in bottom row. 
CD40 was labeled prior to AIG treatment. In both cases, no internalization of the labeled receptor was detected (Figure 3E, F), demonstrating that AIG induces specific internalization of the BCR. (The slight shift in CD40 staining probably results from the upregulation of CD40 in response to AIG treatment.) Finally, to test whether stimulation of TLR4 with LPS or CD40 with anti-CD40 induces TLR4 or CD40 internalization, we fluorescently labeled TLR4 or CD40, then treated cells with the corresponding ligands. In the case of TLR4 stimulation with LPS, no internalization is detected (Figure 3B). Anti-CD40 stimulation induces a rapid receptor shedding phenomenon [17] and so it is difficult to directly compare the results of these samples with the other treatment conditions. However, no evidence for internalization was found (Figure 3I). Thus, AIG induces a ligand-specific, receptorspecific endocytic process that is likely designed to capture specific antigen for processing and presentation.

Finally, MHC class II expression would be expected to be high in B cells undergoing antigen processing and presentation. We found that following overnight stimulation with anti-IgM, CD40L, and LPS, Class II expression on anti-IgM treated cells is sustained, while in CD40L and LPS treated cells Class II expression is significantly downregulated (Figure 4). This ligand-specificity for maintenance of Class II on the surface of anti-IgM-treated cells is interesting because it suggests that B cells constitutively express a high level of Class II on the cell surface in anticipation of antigen presentation, which is then down-regulated in stimulated cells unless they are stimulated through the BCR. This idea that B cells are primed to undergo antigen processing and presentation supports observations in the literature that antigen processing and

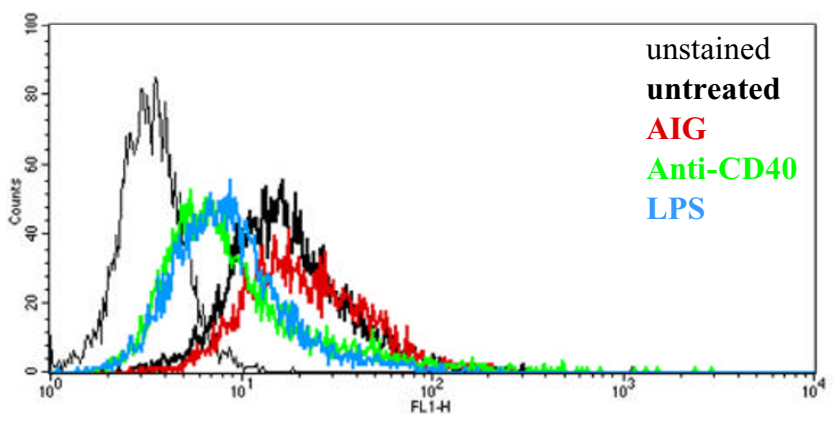

Anti-I-A ${ }^{\mathrm{d}}$

\section{Figure 4}

Class II MHC expression in AIG, anti-CD40, and LPS stimulated WEHI-23 I. Flow cytometric analysis of Class II I-A d expression in WEHI-23I in response to overnight stimulation with AIG (red), anti-CD40 (green), and LPS (blue) or media alone (thick black line). Thin black line represents the unstained control. presentation is accelerated with BCR stimulation. Further, our preliminary data indicate that B cells show enhanced stimulation of antigen-specific $\mathrm{T}$ cell clones in response to BCR stimulation (data not shown).

\section{Discussion \\ CLASSIFI analysis}

In this paper we report the analysis of gene expression responses of B lymphocytes to a panel of extracellular ligands using CLASSIFI, a statistical approach that uses GO annotation to identify significant co-clustering of related genes, thus linking biological function with gene expression patterns derived from microarray experiments. CLASSIFI circumvents two traditional limitations associated with microarray expression analysis - the effects of experimental and biological noise, and the variable depth of knowledge of individual genes in the probe set. A wellcharacterized gene has relatively precise annotations that reach deep into the GO hierarchy, while a poorly-characterized gene is only annotated with high level terms. By capturing the entire ontology parentage of each gene, CLASSIFI overcomes limitations associated with variable depth-of-knowledge associated with most gene sets. In addition, the probability calculation used in CLASSIFI is relatively robust to the addition of experimental noise, allowing the use of less stringent data filtering approaches, which reduces the false negative discovery rate without the usual associated increase in false positives. Indeed, increasing the SAM FDR followed by CLASSIFI analysis increase the number of endocytosis-related genes while maintaining similar gene cluster classifications (data not shown).

Our analysis focused on the AIG-specific Gene Cluster $\# 18$, which was statistically classified as an intracellular transport-related gene cluster. Inspection of the entire gene list leads to the hypothesis that Gene Cluster \#18 classification reflects the broader biological process of BCR-mediated endocytosis, vesicle acidification and trafficking, and antigen processing and presentation. CLASSIFI should be considered a hypothesis-generating tool that requires experimental validation. Several predictions of our hypothesis were confirmed experimentally, including ligand-specific endocytosis induction and $\mathrm{MHC}$ class II expression.

It should be noted that although we have used gene ontology annotation as a means of gene classification, any gene description scheme of interest could be used with the CLASSIFI approach to link experimental variables with legacy knowledge through gene expression microarray data. 
Table 4: Manual curation of Gene Cluster \#1 8 genes

\begin{tabular}{|c|c|c|c|c|c|}
\hline & Protein description & Gene Sym Symbol & LocusLink ID & Function & Reference \\
\hline \multirow[t]{38}{*}{ A } & CD72 & Cd72 & 12517 & BCR coreceptor & $32-3435$ \\
\hline & dual specificity phosphatase 14 & Duspl4 & 56405 & lymphocyte signaling & 36 \\
\hline & mitogen activated protein kinase kinase kinase kinase I & Map4kl & 26411 & lymphocyte signaling & $37-39$ \\
\hline & mitogen activated protein kinase kinase 3 & Map2k3 & 26397 & lymphocyte signaling & 40,41 \\
\hline & serine/threonine kinase receptor associated protein & Strap & 20901 & TGFbeta signaling & 42 \\
\hline & dishevelled associated activator of morphogenesis I & Daam I & 208846 & Wnt signaling & 43 \\
\hline & FK506 binding protein Ia & Fkbpla & 14225 & BCR signaling/apoptosis & $44-46$ \\
\hline & $\begin{array}{l}\text { nuclear factor of activated T-cells, cytoplasmic } 2 \text { interacting } \\
\text { protein }\end{array}$ & Nfatc2ip & 18020 & BCR signaling/apoptosis & $44-46$ \\
\hline & sorting nexin 5 & Snx5 & 69178 & endocytosis & 47,48 \\
\hline & IQ motif containing GTPase activating protein I & lqgapl & 29875 & vesicle formation & 49,50 \\
\hline & amyotrophic lateral sclerosis 2 (juvenile) homolog (human) & Als2 & 74018 & endosome fusion/Rab GEF & $5 \mathrm{I}, 52$ \\
\hline & RABI8, RAS family & Rabl8 & 19330 & endocytosis/vesicle recycling & $53-5656$ \\
\hline & RAB22, RAS family & Rab22a & 19334 & early endosome trafficking & 56,57 \\
\hline & Proton pump, subunit VOB (2I kDa) & Atp 6v0b & 114143 & vesicle acidification & $58-60$ \\
\hline & Proton pump, subunit VIGI (I3 kDa) & Atp6vlgI & 66290 & vesicle acidification & $58-60$ \\
\hline & Proton pump, subunit $\mathrm{VICI}(42 \mathrm{kDa})$ & Atp6vlcl & 66335 & vesicle acidification & $58-60$ \\
\hline & similar to Proton pump, subunit VIF & & 76610 & vesicle acidification & $58-60$ \\
\hline & Proton pump accessory protein 2 & Atp6ap2 & 70495 & vesicle acidification & 61,62 \\
\hline & Chloride channel 7 & Clen7 & 26373 & vesicle $\mathrm{pH}$ regulation & 63,64 \\
\hline & dystrobrevin binding protein I (dysbindin) & Dtnbpl & 94245 & lysosome formation & 65 \\
\hline & cystatin B & Cstb & 13014 & cathepsin protease inhibitor & $66-68$ \\
\hline & hexosaminidase $\mathrm{A}$ & Hexa & $1521 \mid$ & hydrolase & $69-71$ \\
\hline & $\begin{array}{l}\text { ceroid lipofuscinosis, neuronal 3, juvenile (Batten, Spielmeyer- } \\
\text { Vogt disease) }\end{array}$ & $C \ln 3$ & 12752 & lysosome function & 72 \\
\hline & HSP70 binding protein & Hspbpl & 66245 & $\mathrm{Ag}$ processing/loading & 73 \\
\hline & similar to HSPCI 35 & & 66067 & chaperone (?), GTPase (?) & \\
\hline & HSPC245 homolog & & & chaperone (?) & \\
\hline & $\begin{array}{l}\mathrm{N} \text {-ethylmaleimide sensitive fusion protein attachment protein } \\
\text { alpha }\end{array}$ & Napa & 108124 & vesicle fusion & 74,75 \\
\hline & RAB9, RAS family & Rab9 & 56382 & vesicle tethering & 76,77 \\
\hline & activating transcription factor I & Atfl & 11908 & MHC expression & 78 \\
\hline & Sec6I alpha & Sec6lal & 53421 & ER translocation & 79 \\
\hline & signal sequence receptor, alpha & Ssrl & 107513 & MHCll chaperone & 80 \\
\hline & calmegin & Clgn & 12745 & MHC chaperone & 81,82 \\
\hline & similar to signal peptidase SPC22/23 & & 76687 & secretory protein processing & 83 \\
\hline & vacuolar protein sorting 29 & Vps29 & 56433 & retrograde vesicle transport & 84,85 \\
\hline & reticulon 3 & Rtn3 & 20168 & exocytosis & 86,87 \\
\hline & tubulin, alpha 6 & Tuba6 & 22146 & cytoskeletal trafficking & 88,89 \\
\hline & CD63 & Cd63 & 12512 & MHCII coreceptor & $90-92$ \\
\hline & source of immunodominant MHC-associated peptides & Simp & 68292 & MHC peptide & 93 \\
\hline \multirow[t]{5}{*}{ B } & 24-dehydrocholesterol reductase & Dher24 & 74754 & Cholesterol biosynthesis & 94 \\
\hline & fatty acid binding protein 5 , epidermal & Fabp5 & 16592 & $\begin{array}{l}\text { Fatty acid intracellular } \\
\text { transport }\end{array}$ & 95 \\
\hline & phosphatidylethanolamine binding protein & $\mathrm{Pbp}$ & 23980 & Membrane lipid transport & 96 \\
\hline & prostaglandin D2 synthase 2 , hematopoietic & Ptgds2 & 54486 & & \\
\hline & peroxisome biogenesis factor I & Pexl & 71382 & Peroxisomal protein tranport & 97 \\
\hline \multirow[t]{3}{*}{ C } & beclin I (coiled-coil, myosin-like BCL2-interacting protein) & Becnl & 56208 & Tumor suppression & 98,99 \\
\hline & caspase 4 , apoptosis-related cysteine protease & Casp4 & 12363 & Apoptosis & $100-102$ \\
\hline & Cd27 binding protein (Hindu God of destruction) & Siva & 30954 & Apoptosis & 103,104 \\
\hline \multirow[t]{3}{*}{ D } & polymyositis/scleroderma autoantigen 2 & Pmscl2 & 50912 & RNA processing autoantigen & 105 \\
\hline & Sjogren's syndrome/scleroderma autoantigen I homolog (human) & Ssscal & 56390 & centromeric autoantigen & 106 \\
\hline & amyotrophic lateral sclerosis 2 (juvenile) homolog (human) & Als2 & 74018 & endosome fusion/Rab GEF & 51,52 \\
\hline
\end{tabular}

Genes found in Gene Cluster \#18 with functions related to (A) intracellular trafficking, BCR signaling, vesicle processing and function, and antigen processing and presentation, (C) apoptosis, and (D) B cell-related autoimmune disease. (B) Genes annotated with "transporter" activity whose roles are not yet known to be associated with intracellular trafficking. 
Identification of putative components of BCR-mediated antigen capture, processing, and presentation (see Table 4 for reference to this section)

Based on the genes responsible for Gene Cluster \#18 classification (Table 3), we hypothesized that BCR engagement activates receptor-mediated endocytosis, vesicle acidification, vesicle trafficking, and antigen processing and presentation. We manually curated the AIG-specific cluster gene list and found a total of 38 genes, including those identified using CLASSIFI, that might be involved based on the molecular functions defined in other cell systems and biological processes from the literature (Table $4 \mathrm{~A})$. Figure 5 shows a schematic representation of the $\mathrm{B}$ cell antigen processing and presentation pathway indicating the putative roles played by these genes.
Several genes known to be involved in signal transduction were found in Gene Cluster \#18; some have been demonstrated to play a role in BCR signaling while others are involved in signaling pathways in other cell types and are candidates for new BCR signaling components that stimulate the endocytic process (Table $4 \mathrm{~A}$ ). Activation of protein kinases, including members of the MAP kinase family, in response to BCR engagement is well documented; thus Strap, Map4k1 (Hpk1) and Map2k3 may also play a role in BCR signaling. Indeed, Map4k1 is expressed in hematopoietic cells and is required for activation-induced $\mathrm{T}$ cell death following TCR stimulation, and Map2k3 is required for IL-12 production by macrophages and dendritic cells, and antigen-mediated activation of $\mathrm{T}$ cells. CD72 has been found to regulate the

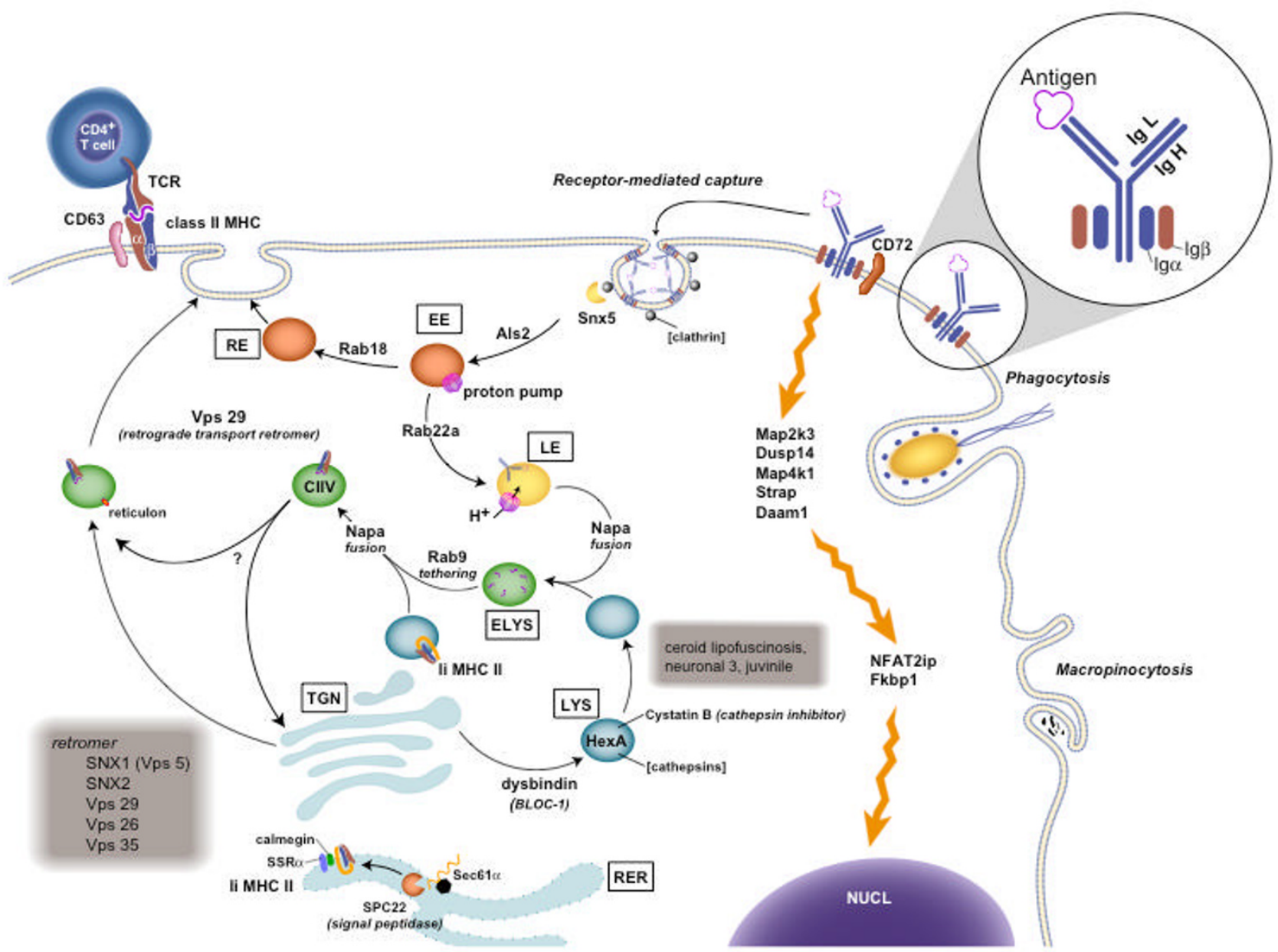

Figure 5

Gene Cluster \#18 contains genes involved in several aspects of vesicle processing, intracellular trafficking, and antigen processing and presentation. A manual curation of the gene list comprising Gene Cluster \#I8 resulted in this detailed model of intracellular transport processes in $\mathrm{B}$ cells (refer to text for details). $\mathrm{EE}=$ early endosome, $\mathrm{LE}=$ late endosome, $\mathrm{RE}=$ recycling endosome, $\mathrm{ELYS}=$ endolysosome, $\mathrm{LYS}=$ lysosome, $\mathrm{RER}=$ endoplasmic reticulum, TGN = trans-Golgi network, NUCL = nucleus. 
cellular response to BCR signaling either through the recruitment of the SHP-1 phosphatase thereby dampening BCR signaling, or by cooperating with BCR signaling to prevent apoptosis in immature B cells. The Dusp14 dual specificity phosphatase has been found to associate with the CD28 co-receptor and dampen TCR-mediated signaling in T cells by inactivation of MAP kinases, suggesting that it may regulate BCR signaling in a similar fashion. Daam1 is involved in Wnt signaling in Xenopus embryogenesis. Strap binds to the TGF beta type I receptor and inhibits downstream signaling. Whether these proteins might play a role in regulating BCR signaling remains to be determined. The NF-ATc2 isoform has been found to participate in the BCR-induced apoptosis in Bcell-derived Burkitt's lymphoma cell lines, thus the presence of Nfatc2ip and Fkbp1 suggests that these interacting proteins may also be important in regulating $\mathrm{Ca}^{++} / \mathrm{cal}-$ modulin/calcineurin/NFAT signaling in B cells.

A large proportion of genes in Gene Cluster \#18 encode proteins with roles in endocytosis, vesicle trafficking, vesicle acidification, molecular processing and protein secretion. In most cases these roles have been defined in other cell systems. Since little is known about the molecular details of these processes in receptor-mediated antigen capture and MHC class II-dependent antigen processing and presentation in B cells, the possibility that Gene Cluster \#18 has produced a putative list of proteins that coordinate these activities is intriguing.

Snx5, a member of the sorting nexin family, has been found to interact with clathrin in skeletal muscle. Clathrin has been implicated in facilitating membrane invagination during receptor-mediated endocytosis in B cells. The presence of Snx5 in this cluster suggests that it may help mediate this process. The Als2 protein acts as a guanine nucleotide exchange factor for Rab5 and Rac1, and stimulates early endosome fusion. Rab proteins are small GTPases with homology to Ras that play key roles in vesicle transport: Rab18 has been found to localize near the apical and basolateral plasma membrane in epithelial cells of the kidney and intestine and Rab22a has been found to localize to the plasma membrane and early endosomes. Iqgap1 is a scaffolding protein with multiple protein-protein interaction domains and a GTPase activation protein (Gap) domain that stimulates the hydrolytic activity of Ras family members. Iqgap 1 has also been found to localize to areas of membrane ruffling and newly formed vesicles in astrocytoma cells.

Genes encoding homologs to several components of the vesicle-type proton pump were found in Gene Cluster \#18, including Atp6v0b, Atp6v1g1, Atp6v1c1, and Atp6v1f and the proton pump accessory protein Atp6ap2. Additional proton pump components were also found to be induced in an AIG-specific manner by RT-PCR (Atp6v0c, Atp6va1, Atp6v1h and Atp6v1a1). Together with the vesicle-specific chloride channel Clcn7, these proteins are likely to play a role in the acidification of the endocytic vesicles in preparation for their fusion with lysosomes to facilitate antigen hydrolysis. Proton pump components can serve as a membrane anchor point for SNARE proteins. Napa appears to mediate the tethering of these vesicles in preparation for fusion. Rab9 also appears to play a role in vesicle fusion since mutations in Rab9 lead to the accumulation of lipid-rich vesicles.

Several proteins involved in lysosome formation and antigen processing were found in Gene Cluster \#18. Dysbindin binds to dystobrevins and is a component of the biogenesis of lysosome-related organelles complex 1 in mouse liver, which regulates trafficking to lysosomal organelles. Mutations in the Cln 3 gene leads to a lysosomal storage disorder associated with the accumulation of lipopigment-laden vesicles. Hexosaminidase $\mathrm{A}$ is a $\mathrm{pH}$ sensitive hydrolase. A variety of cathepsins are involved in MHC Class II antigen processing and presentation. None of the probes for these genes passed our data filtering process, however the cathepsin inhibitor Cystatin B was found in Gene Cluster \#18, suggesting that it might play a role in regulating cleavage site selection by modifying the relative activities of proteases involved in antigen processing and peptide loading. Hspbp1 may facilitate antigen processing by regulating the chaperone function of Hsp70, which has been associated with the presentation of myelin basic protein though MHC class II in multiple sclerosis.

Several genes involved in MHC class II expression were found in the AIG-specific gene cluster. Atf1 is a transcription factor that activates the promoter of the class II transactivator (CIITA). Translocation of nascent MHC class II peptide chains into the lumen of the endoplasmic reticulum involves the function of the Sec61 translocation complex, the signal sequence receptor Ssr1 (a.k.a. TRAP alpha) and the signal peptidase SPC22. Calmegin (Clgn) is a $\mathrm{Ca}^{++}$ binding chaperone protein with significant homology to calreticulin and calnexin, an ER chaperone protein that regulates the assembly of MHC class II with the Ii invariant chain.

Vesicles containing peptide-loaded MHC class II are transported to the plasma membrane for fusion and exposure on the cell surface, perhaps by traveling back through the TGN into the secretory pathway. The Vsp29 protein has been found to facilitate this kind of retrograde TGN transport in yeast. In neurons, reticulon 3 is associated with synaptophysin in tubulovesicular structures and may play a role in the process of vesicle secretion. CD63, an MHC 
class II co-receptor, may play a role in regulating MHC receptor compartmentalization.

38 genes found in Gene Cluster \#18 encode proteins that have some connection with signaling, antigen capture, vesicle transport, vesicle acidification or MHC class II expression, suggesting that activation of $\mathrm{B}$ cells through the BCR is inducing the expression of genes involved in MHC class II antigen processing and presentation. The activation of class II presentation by antigen receptor engagement in B cells has been described extensively. The findings reported here are novel in that microarray results combined with CLASSIFI analysis have provided a list of genes that may be involved in this important immunological process.

Finally, it is intriguing to note the presence of genes involved in the regulation of apoptosis and autoimmunity (Table 4C and 4D) in Gene Cluster \#18, given the known function of the BCR in negative selection and the induction of autoimmunity.

\section{Transcriptional positive feedback}

The changes in mRNA levels for these genes involved in vesicle trafficking might be necessary to stimulate this biological process in AIG-stimulated B cells. However, the kinetics of the mRNA changes compared with the rapid induction of endocytosis suggests that this may not be the case. Elevated mRNA levels for these genes was found at 2 and $4 \mathrm{hr}$, but not at 0.5 or $1 \mathrm{hr}$ post-stimulation. However, BCR endocytosis was maximally stimulated by $15 \mathrm{~min}$ utes. The rapid induction of endocytosis suggests that at least the initiation of this process is activated through post-transcriptional mechanisms. This finding suggests that the AIG-specific transcriptional reprogramming observed in response to BCR stimulation may reflect positive feedback regulation in which expression of proteins that have already been activated is increased either as a means to amplify or sustain the process. Perhaps components of this important biological process are present at low levels in resting cells, and levels increase in response to appropriate environmental cues. This kind of regulatory process might allow cells to respond rapidly to a broad set of variables in their changing environment while conserving energy and materials while in a resting state.

\section{Conclusion}

In this paper, we describe a bioinformatics analysis of a $\mathrm{B}$ cell microarray dataset using CLASSIFI to determine the biological significance of microarray gene clusters defined by ligand-specific B cell responses. Importantly, results from laboratory experimentation support the hypotheses derived from this microarray data mining exercise. This work is a model for immunologists and other biologists for utilizing the growing field of bioinformatics for microarray data mining, hypothesis generation and hypothesis testing. Furthermore, the results from this analysis provide a foundation for a more detailed understanding of the $\mathrm{B}$ cell antigen processing and presentation pathway.

\section{Methods \\ Primary B cell isolation and culture}

Isolation of primary splenic murine B cells was performed as described in the Alliance for Cellular Signaling (AfCS)/ Nature Signaling Gateway website [18]. Briefly, splenocytes from 6-10 week old C57BL/ 6 mice were subjected to a magnetic bead negative selection procedure (Miltenyi Biotech, Auburn, CA) to remove CD43+ and Mac-1+ cells, resulting in an enriched population of resting $B$ cells that was an average of $96 \% \mathrm{~B} 220+$, as determined by flow cytometry [19]. Purified B cells were cultured in supplemented Iscove's Modified Dulbecco's Medium [20] with $100 \mathrm{U} / \mathrm{ml}$ penicillin and $100 \mu \mathrm{g} / \mathrm{ml}$ streptomycin (Invitrogen, Carlsbad, CA) at $37^{\circ} \mathrm{C}$ under $5 \% \mathrm{CO}_{2}$. For microarray and internalization experiments, cells were treated for $0.5 \mathrm{hr}, 1 \mathrm{hr}, 2 \mathrm{hr}$, and $4 \mathrm{hr}$ with media alone, or with mu chain specific Goat anti-mouse immunoglobulin, (AIG) (Jackson Immunoresearch) at $45 \mu \mathrm{g} / \mathrm{ml}$, hamster antimouse CD40 monoclonal antibody, clone HM40-3 (BD Pharmingen) at $9.73 \mu \mathrm{g} / \mathrm{ml}$, or lipopolysaccharide (LPS) (Sigma-Aldrich) at $40 \mu \mathrm{g} / \mathrm{ml}$. For real-time PCR experiments, cells were treated with anti-IgM at $20 \mu \mathrm{g} / \mathrm{ml}$ or anti-CD40 at $625 \mathrm{ng} / \mathrm{ml}$.

\section{Microarray analysis and clustering}

Microarray-related experimental protocols can be found at the AfCS/Nature website at [21]; protocol IDs are: PP00000009-RNA extraction, PP00000019-sample preparation and hybridization. Briefly, RNA samples isolated from B cells treated with a panel of 32 ligands were compared with untreated samples using a microarray chip containing $15,494 \mathrm{cDNA}$ probes printed on 15,832 spots representing 10,615 unique MGI gene matches (as of 12/ $31 / 03$ ). $38 \%$ of the probes have not been assigned a gene name, 96\% come from the RIKEN FANTOM collection, $3 \%$ from the Minoro Ko National Institute of Aging collection, and the rest from the Research Genetics and Genome Systems collections. RNA samples were used to generate Cy5- and Cy3-labeled cDNA targets (from sample RNAs and RBC-depleted total splenocyte RNA, respectively) and were hybridized together. All samples were run in triplicate except for $1 \mathrm{hr}$ and $4 \mathrm{hr}$ untreated controls, which were run in quadruplicate. Arrays were scanned using the Agilent Scanner G2505A (Agilent Technologies, Palo Alto, $\mathrm{CA})$. Image files were analyzed using the Agilent G2566AA Feature Extraction software version A.6.1.1. The raw data from these experiments is available at [22]. Spot features on each array were filtered to remove those values that were saturated, non-uniform, or below background. 
Statistical filtering was accomplished using Significance Analysis of Microarrays (SAM) [23]. Features found by SAM to be differentially expressed between samples and time-matched untreated controls at a false discovery rate (FDR) of $1 \%$ were included for further analysis. Input for SAM were background-subtracted, dye bias- and interarray variance-normalized Cy5 fluorescence intensity values, which represent expression level of array features. Only features with more than two replicates were used in the SAM analysis. 100 random permutations were done for each comparison of treated to time-matched control samples. Values of $+1,-1$, or 0 were given to genes that were found by SAM to be significantly upregulated, downregulated, or unchanged (respectively) compared to timematched untreated controls. These values were used to categorically group genes together based on their expression response patterns.

\section{CLASSIFI analysis}

Cluster Assignment for Biological Inference (CLASSIFI) was developed as a method for statistical evaluation of Gene Ontology $^{\mathrm{TM}}$ (GO) term co-clustering (Figure 1A). CLASSIFI is predicated on the postulate that genes involved in the same biological process are coordinately expressed; examples of coordinate expression of interacting proteins in eukaryotes has been described [24-27]. Following data transformation, filtering, normalization, standard expression clustering approaches and gene cluster membership assignment, the following steps are performed in the CLASSIFI analysis: 1) remove duplicate probe IDs, 2) extract the primary GO annotations for each gene from a probe database, 3) capture the full GO ancestry for each primary GO annotation from the Gene Ontology $^{\mathrm{TM}}$ database, and 4) calculate the solution for the cumulative hypergeometric distribution equation for every GO term in every gene cluster:

$$
P=1-\sum_{i=0}^{n-1} \frac{\left(\begin{array}{l}
f \\
i
\end{array}\right)\left(\begin{array}{c}
g-f \\
c-i
\end{array}\right)}{\left(\begin{array}{l}
g \\
c
\end{array}\right)}
$$

where $g=$ number of probes in the data set, $c=$ number of probes in the gene cluster, $f=$ number of probes with a given ontology in the data set, $n=$ number of probes with a given ontology in the gene cluster. The hypergeometric distribution calculates the probability $(P)$ that genes with a particular GO term would co-cluster by chance given the proportion of genes annotated with this GO term in the entire data set. A web interface for use of the CLASSIFI method with data derived from cDNA, oligonucleotide and Affymetrix microarrays, along with detailed information about CLASSIFI input and output files can be found at the CLASSIFI website [28].

\section{Quantitative real-time reverse-transcription-polymerase chain reaction}

Total RNA was extracted as for the microarray experiments. $1 \mu \mathrm{g}$ of total RNA was treated with DNaseI (Invitrogen), then reverse transcribed at $42^{\circ} \mathrm{C}$ for one hour in a $20 \mu \mathrm{l}$ volume containing $1 \mu \mathrm{l} \mathrm{MMLV} \mathrm{reverse} \mathrm{transcriptase}$ (Invitrogen), $4 \mu \mathrm{l} 5 \mathrm{X}$ buffer (Invitrogen), $0.5 \mathrm{mM}$ dNTPs (Invitrogen), and $5 \mathrm{ng} / \mu \mathrm{l} \mathrm{pd}(\mathrm{N})_{6}$ (Amersham). Following inactivation at $70^{\circ} \mathrm{C}$ for $20 \mathrm{~min}$, PCR reactions were set up in a $20 \mu \mathrm{l}$ volume using Sybr Green Master Maker (Applied Biosystems). Thermal cycling began with a denaturation step of 10 minutes at $95^{\circ} \mathrm{C}$, followed by 40 cycles of $95^{\circ} \mathrm{C}$ for 15 seconds (denaturation) and $60^{\circ} \mathrm{C}$ for 1 minute (annealing and extension). PCR reactions were performed in the ABI Prism 7700 Sequence Detector (PE Biosystems, Foster City, CA), and data collected and analyzed with the Sequence Detector software (PE Biosystems). Standard curves were generated using RNA isolated from RBC-depleted mouse splenocytes. RT-PCR of mouse $18 \mathrm{~S}$ rRNA levels was used for normalization. Data from treated samples were compared to untreated samples, giving values representing the fold change in gene expression relative to untreated samples. PCR primers were designed using Primer3 software [29]: ATP6v0Bc" forward (f) 5'gaaccccagcctctttgtaa3', reverse (r) 5'cccatcttcactctggaggt3'; ATP6v1c1 (f) 5'tgcttgccaaagaggtaaca3', (r) 5'tcgctgcatgtagtttctcc3'; sorting nexin V (f) 5'gggagaaggggaaggatcta3', (r) 5'catgggtggacacagtcttc 3 '; vacuolar protein 295 (f) 5 'ctgcagaggcagtttgatgt3', (r) 5'ggcagaacctgggttaatgt 3'; ATP6v0c (f) 5'atgtcagtcatgaggccaga3', (r) 5'agcgataagtactgccacca3'; ATP6v0a1 (f) 5'tccacccagtctgtaggtga3'. (r) 5'atcatgatcagggtgcagaa3'; ATP6v1h (f) 5'gatgctgctgtcccaactaa3', (r) 5'agaaatcatctgcccctgaa3'; $\quad$ ATP6v1a1 (f) 5'gaattatgatgcgtccgatg 3', (r) 5'cgcctgggatagcagtagtt 3'. Mouse 18S PCR primers sequences are from [30]: (f) 5'gtaacccgttgaaccccatt3', (r) 5'ccatccaatcggtagtagcg3'.

\section{Internalization assays and flow cytometry}

$1 \times 10^{6}$ WEHI-231 cells (a mouse B cell lymphoma line) were pre-stained for $10 \mathrm{~min}$ at $4{ }^{\circ} \mathrm{C}$ with monoclonal antibodies to cell surface receptors: Rat anti-IgM-FITC clone R6-60.2 or clone II/40 (BD Pharmingen), Rat anti-CD40FITC clone 3/23 (BD Pharmingen), or Rat anti-TLR4/ MD2-PE clone MTS510 (eBiosciences). Following 2 washes in PBS/2\% FBS/2 mM EDTA, cells were cultured and stimulated using the aforementioned ligand concentrations in RPMI supplemented with 10\% FBS (Hyclone), $100 \mathrm{U} / \mathrm{ml}$ penicillin, $100 \mu \mathrm{g} / \mathrm{ml}$ streptomycin (Invitrogen, Carlsbad, CA), sodium pyruvate, HEPES, and 2-ME (Invitrogen). Following incubation at $37^{\circ} \mathrm{C}$ with $5 \% \mathrm{CO}_{2}$ for various time periods, cells were harvested and incubated at $4{ }^{\circ} \mathrm{C}$ for 5 minutes in $0.2 \mathrm{M}$ Acetic acid/0.5 M NaCl to strip off staining antibodies [31], or in PBS/2\% FBS/2 mM 
EDTA (control). Following 2 washes in $0.2 \mathrm{M}$ Acetic acid/ $0.5 \mathrm{M} \mathrm{NaCl}$ or PBS/2\% FBS/2 mM EDTA, respectively, samples were fixed in 1\% paraformaldehyde. Data were acquired using a FACSCalibur ${ }^{\mathrm{TM}}$ flow cytometer and analyzed using CellQuest ${ }^{\mathrm{TM}}$ software (Becton Dickinson Immunocytometry Systems).

MHC class II expression was measured by flow cytometric analysis using FITC-conjugated antibody against $\mathrm{I}^{\mathrm{d}} \mathrm{A}^{\mathrm{d}}$ clone 39-10-8 (BD Pharmingen).

\section{BCR localization by immunofluorescence microscopy}

$1 \times 10^{6}$ WEHI-231 cells were harvested and resuspended in $100 \mu \mathrm{l} \mathrm{PBS}$ containing 2\% FBS. $2 \mu \mathrm{l}$ of rat anti-IgM-FITC clone R6-60.2 antibody was added, and cells incubated on ice for 10 minutes to allow BCR staining. R6-60.2 was determined to be non-stimulating because it did not flux calcium or induce detectable tyrosine phosphorylation in these cells (data not shown). Following one wash in PBS/ 2\%FBS, cells were resuspended in 100 ul phenol-red free growth medium (Invitrogen) and kept on ice prior to stimulation. Cells were stimulated by addition of ligands at the following concentrations: AIG, $20 \mu \mathrm{g} / \mathrm{ml}$; HM40-3, $9.73 \mu \mathrm{g} / \mathrm{ml}$; or LPS, $40 \mu \mathrm{g} / \mathrm{ml}$. Images were captured at room temperature immediately following ligand stimulation for up to $10 \mathrm{~min}$. Using the Zeiss Axioplan 2 upright fluorescence microscope (Carl Zeiss, Inc, Thornwood, NY), images were captured with the 60X objective under oil immersion using the OpenLab ${ }^{\mathrm{Tm}}$ software, version 4.0.1 (Improvision, Boston, MA). 2 images were captured for each field of view: one for detection of FITC fluorescence, and one for differential interference contrast (DIC) imaging of cells. Images were processed using OpenLab ${ }^{\mathrm{TM}}$.

\section{Abbreviations Ligand abbreviations:}

2MA - 2-Methyl-thio-ATP

AIG - Antigen (Anti-Ig)

BAF - BAFF (B-cell activating factor)

BLC - BLC (B-lymphocyte chemoattractant)

BOM - Bombesin

40L - CD40 ligand

CGS - CGS-21680 hydrochloride (2-p-[2-Carboxyethyl]phenethylamino-5'-N-ethylcarboxamidoadenosine)

CPG - CpG-Containing Oligonucleotide

DIM - Dimaprit
ELC - ELC (Epstein Barr Virus-induced molecule-1 Ligand Chemokine)

FML - fMLP (formyl-Met-Leu-Phe)

GRH - Growth hormone-releasing hormone

IGF - Insulin-like growth factor 1

IFB - Interferon-beta

IFG - Interferon-gamma

I10 - Interleukin 10

I04 - Interleukin 4

LPS - Lipopolysaccharide

LB4 - Leukotriene B4 (LTB4)

LPA - Lysophosphatidic acid

M3A - MIP3-alpha (Macrophage inflammatory protein-3)

NEB - Neurokinin B

NPY - Neuropeptide Y

NGF - NGF (Nerve Growth Factor)

PAF - Platelet activating factor

PGE - Prostaglandin E2

SDF - SDF1 alpha (Stromal cell derived factor-1)

SLC - SLC (Secondary lymphoid-organ chemokine)

S1P - Sphingosine-1-phosphate

TER - Terbutaline

TNF - Tumor necrosis factor-alpha

TGF - Transforming growth factor-beta 1

Other Abbreviations:

BCR - B cell receptor

CLASSIFI - Cluster Assignment for Biological Inference

GO - Gene Ontology 
SAM - Significance Analysis of Microarrays

TLR4 - Toll-Like Receptor 4

\section{Authors' contributions}

JL carried out the microarray clustering, CLASSIFI analysis and experimental validation, and drafted the manuscript. RSS and DM participated in the microarray analysis and CLASSIFI design and implementation. ER and RCH participated in experimental validation. JC and PY participated in implementing the CLASSIFI algorithm as a webbased application. BS and SS participated in the CLASSIFI design and implementation. SC participated in the microarray analysis. RHS conceived of the study and the CLASSIFI algorithm, participated in its design, coordinated the study and helped to draft the manuscript. All authors participated in critical review of the manuscript and give final approval for the submitted manuscript.

\section{Additional material}

\section{Additional File 1}

CLASSIFI input file. The CLASSIFI input file was generated following microarray data clustering. It lists probe IDs, Gene names, and Cluster IDs resulting from categorical clustering of processed data from $B$ cells stimulated with anti-CD40, LPS, and AIG. This input file was uploaded at the CLASSIFI website [28], which provides a web interface for the use of CLASSIFI.

Click here for file

[http://www.biomedcentral.com/content/supplementary/14712105-7-237-S1.xls]

\section{Additional File 2}

CLASSIFI output file. Complete output file resulting from CLASSIFI analysis of the data set. Clusterid = gene clusters resulting from categorical clustering of processed data from B cells stimulated with anti-CD40, LPS, and AIG. GO id = a unique Gene Ontology identifier that corresponds to a GO term, which is used to describe gene products based on molecular function, biological process, or cellular component. $g=$ number of probes in the data set, $f=$ number of probes with associated GO id in the data set, $c=$ number of probes in the gene cluster, $n=$ number of probes with associated GO id in the gene cluster. Expt $=$ the expected number of occurrences of a given GO id in a given cluster of size ( $n$ ) based on a random distribution. Prob $=$ the probability that the GO id co-cluster pattern has occurred by chance.

Click here for file

[http://www.biomedcentral.com/content/supplementary/14712105-7-237-S2.xls]

\section{Additional File 3}

CLASSIFI GO file. Complete list of all GO ids (representing the entire GO ancestry) associated with each probe ID.

Click here for file

[http://www.biomedcentral.com/content/supplementary/1471-

2105-7-237-S3.xls]

\section{Acknowledgements}

We thank the Alliance for Cellular Signaling (AfCS) for providing materials, methods, and expertise in the development of this work. The following authors are members of the AfCS: RSS, DM, BS, RCH, SC, SS, and RHS.

\section{References}

I. Hsueh RC, Scheuermann RH: Tyrosine kinase activation in the decision between growth, differentiation, and death responses initiated from the $\mathbf{B}$ cell antigen receptor. Adv Immunol 2000, 75:283-316.

2. DeFranco AL: Molecular aspects of B-lymphocyte activation. Annu Rev Cell Biol 1987, 3:143-78.

3. Bryant PW, Lennon-Dumenil AM, Fiebiger E, Lagaudriere-Gesbert C, Ploegh HL: Proteolysis and antigen presentation by MHC class II molecules. Adv Immunol 2002, 80:7I-I I4.

4. Siemasko K, Clark MR: The control and facilitation of MHC class II antigen processing by the BCR. Curr Opin Immunol 200I, 13:32-6.

5. Lanzavecchia A, Bove S: Specific B lymphocytes efficiently pick up, process and present antigen to $\mathbf{T}$ cells. Behring Inst Mitt 1985:82-7.

6. McGovern EM, Moquin AE, Caballero A, Drake JR: The effect of B cell receptor signaling on antigen endocytosis and processing. Immunol Invest 2004, 33:143-56.

7. Brown BK, Li C, Cheng PC, Song W: Trafficking of the Igalpha/ Igbeta heterodimer with membrane Ig and bound antigen to the major histocompatibility complex class II peptide-loading compartment. J Biol Chem 1999, 274: I I 439-46.

8. Zhu X, Hart R, Chang MS, Kim JW, Lee SY, Cao YA, Mock D, Ke E, Saunders B, Alexander A, et al.: Analysis of the major patterns of $B$ cell gene expression changes in response to short-term stimulation with 33 single ligands. J Immunol 2004, 173:7|4I-9.

9. Gene Ontology [http://www.geneontology.org]

10. Ashburner M, Ball CA, Blake JA, Botstein D, Butler H, Cherry JM, Davis AP, Dolinski K, Dwight SS, Eppig JT, et al.: Gene ontology: tool for the unification of biology. The Gene Ontology Consortium. Nature Genetics 2000, 25:25-9.

II. Zhong S, Li C, Wong WH: Software for extracting gene annotation and gene ontology information for microarray analysis. Nucleic Acids Res 2003, 31:3483-6.

12. Draghici S, Khatri P, Martins RP, Ostermeier GC, Krawetz SA: Global functional profiling of gene expression. Genomics 2003, 8I:98-I04.

13. Doniger SW, Salomonis N, Dahlquist KD, Vranizan K, Lawlor SC, Conklin BR: MAPPFinder: using Gene Ontology and GenMAPP to create a global gene-expression profile from microarray data. Genome Biol 2003, 4:R7.

14. Bonferroni Correction [http://mathworld.wolfram.com/Bonfer roniCorrection.html]

15. Kehry MR: CD40-mediated signaling in B cells. Balancing cell survival, growth, and death. J Immunol 1996, 156:2345-8.

16. Ha YJ, Lee JR: Role of TNF receptor-associated factor 3 in the CD40 signaling by production of reactive oxygen species through association with p40phox, a cytosolic subunit of nicotinamide adenine dinucleotide phosphate oxidase. J Immunol 2004, 172:23I-9.

17. Contin C, Pitard V, Itai T, Nagata S, Moreau JF, Dechanet-Merville J: Membrane-anchored CD40 is processed by the tumor necrosis factor-alpha-converting enzyme. Implications for CD40 signaling. J Biol Chem 2003, 278:3280I-9. Epub 2003 Jun 16

18. Isolation of Resting B Lymphocytes from One or More Groups of Four Mouse Spleens [http://www.signaling-gate way.org/data/cgi-bin/ProtocolFile.cgi?.pid=PP0000000I]

19. Hsueh RC, Roach TIA, Lin K-M, O'Connell TD, Han H, Yan Z: Purification and Characterization of Mouse Splenic B Lymphocytes. AfCS Research Reports 2002.

20. AfCS Solution Protocol [http://www.signaling-gateway.org/data/ cgi-bin/ProtocolFile.cgi?pid=PS00000056]

21. AfCS Protocols [http://www.signaling-gateway.org/data/Proto collinks.html]

22. AfCS Ligand Screen Experiments [http://www.signaling-gate way.org/data/cgi-bin/table.cgi?cellabbr=BC] 
23. Tusher VG, Tibshirani R, Chu G: Significance analysis of microarrays applied to the ionizing radiation response. Proc Natl Acad Sci U S A 2001, 98:51 16-21. Epub 2001 Apr 17

24. Eisen MB, Spellman PT, Brown PO, Botstein D: Cluster analysis and display of genome-wide expression patterns. Proc Natl Acad Sci U S A 1998, 95: |4863-8.

25. Grigoriev A: A relationship between gene expression and protein interactions on the proteome scale: analysis of the bacteriophage T7 and the yeast Saccharomyces cerevisiae. Nucleic Acids Res 200I, 29:3513-9.

26. Ge H, Liu Z, Church GM, Vidal M: Correlation between transcriptome and interactome mapping data from Saccharomyces cerevisiae. Nat Genet 2001, 29:482-6.

27. P Kemmeren, van Berkum NL, Vilo J, Bijma T, Donders R, Brazma A, Holstege FC: Protein interaction verification and functional annotation by integrated analysis of genome-scale data. $\mathrm{Mol}$ Cell 2002, 9: I 133-43.

28. CLASSIFI [http://pathcuricl.swmed.edu/pathdb/CLASSIFI.html]

29. Primer3 [http://frodo.wi.mit.edu/cgi-bin/primer3/ primer3 www.cgi]

30. Schmittgen TD, Zakrajsek BA: Effect of experimental treatment on housekeeping gene expression: validation by real-time, quantitative RT-PCR. J Biochem Biophys Methods 2000, 46:69-8I.

31. Tebar F, Bohlander SK, Sorkin A: Clathrin assembly lymphoid myeloid leukemia (CALM) protein: localization in endocyticcoated pits, interactions with clathrin, and the impact of overexpression on clathrin-mediated traffic. Mol Biol Cell 1999, 1 0:2687-702.

32. Wu HJ, Venkataraman C, Estus S, Dong C, Davis RJ, Flavell RA, S Bondada: Positive signaling through CD72 induces mitogen-activated protein kinase activation and synergizes with $B$ cell receptor signals to induce $X$-linked immunodeficiency $B$ cell proliferation. J Immunol 200I, I67:1263-73.

33. Hokazono $\mathrm{Y}$, Adachi T, Wabl M, Tada N, Amagasa T, Tsubata T: Inhibitory coreceptors activated by antigens but not by antiIg heavy chain antibodies install requirement of costimulation through CD40 for survival and proliferation of B cells. J Immunol 2003, I 7 I: I835-43.

34. Fujiwara N, Fusaki N, Hozumi N: CD72 stimulation modulates anti-IgM induced apoptotic signaling through the pathway of NF-kappaB, c-Myc and p27(Kipl). Microbiol Immunol 2004, 48:59-66.

35. Adachi T, Flaswinkel H, Yakura H, Reth M, Tsubata T: The B cell surface protein CD72 recruits the tyrosine phosphatase SHP-I upon tyrosine phosphorylation. J Immunol 1998, 160:4662-5.

36. Marti F, Krause A, Post NH, Lyddane C, Dupont B, Sadelain M, PD King: Negative-feedback regulation of CD28 costimulation by a novel mitogen-activated protein kinase phosphatase, MKP6. I Immunol 2001, 1 66:197-206.

37. Schulze-Luehrmann J, Santner-Nanan B, Jha MK, Schimpl A, Avots A, Serfling E: Hematopoietic progenitor kinase I supports apoptosis of T lymphocytes. Blood 2002, 1 00:954-60.

38. Hu E, Kim JB, Sarraf P, Spiegelman BM: Inhibition of adipogenesis through MAP kinase-mediated phosphorylation of PPARgamma. Science 1996, 274:2100-3.

39. Hu MC, Qiu WR, Wang X, Meyer CF, Tan TH: Human HPKI, a novel human hematopoietic progenitor kinase that activates the JNK/SAPK kinase cascade. Genes Dev 1996, I 0:225 I-64.

40. Tanaka N, Kamanaka M, Enslen H, Dong C, Wysk M, Davis RJ, Flavell RA: Differential involvement of p38 mitogen-activated protein kinase kinases MKK3 and MKK6 in T-cell apoptosis. EMBO Rep 2002, 3:785-9I. Epub 2002 Jul I5

4I. Lu HT, Yang DD, Wysk M, Gatti E, Mellman I, Davis RJ, Flavell RA: Defective IL-I2 production in mitogen-activated protein (MAP) kinase kinase 3 (Mkk3)-deficient mice. Embo J 1999, I 8: 1845-57.

42. Datta PK, Chytil A, Gorska AE, Moses HL: Identification of STRAP, a novel WD domain protein in transforming growth factor-beta signaling. | Biol Chem |998, 273:3467|-4.

43. Habas R, Kato $Y$, He X: Wnt/Frizzled activation of Rho regulates vertebrate gastrulation and requires a novel Formin homology protein Daam I. Cell 200I, I 07:843-54.

44. Healy JI, Dolmetsch RE, Timmerman LA, Cyster JG, Thomas ML, Crabtree GR, Lewis RS, Goodnow CC: Different nuclear signals are activated by the $B$ cell receptor during positive versus negative signaling. Immunity 1997, 6:419-28.

45. Peng SL, Gerth AJ, Ranger AM, Glimcher LH: NFATcI and NFATc2 together control both $T$ and $B$ cell activation and differentiation. Immunity 200I, I 4: I3-20.

46. Kondo E, Harashima A, Takabatake T, Takahashi H, Matsuo $\mathrm{Y}$, Yoshino T, Orita K, Akagi T: NF-ATc2 induces apoptosis in Burkitt's lymphoma cells through signaling via the $B$ cell antigen receptor. Eur J Immunol 2003, 33: I-I I.

47. Teasdale RD, Loci D, Houghton F, Karlsson L, Gleeson PA: A large family of endosome-localized proteins related to sorting nexin I. Biochem J 200I, 358:7-16.

48. Towler MC, Gleeson PA, Hoshino S, Rahkila P, Manalo V, Ohkoshi N, Ordahl C, Parton RG, Brodsky FM: Clathrin isoform CHC22, a component of neuromuscular and myotendinous junctions, binds sorting nexin 5 and has increased expression during myogenesis and muscle regeneration. Mol Biol Cell 2004 15:3181-95. Epub 2004 May 7

49. Mbele GO, Deloulme JC, Gentil BJ, Delphin C, Ferro M, Garin J, Takahashi M, Baudier J: The zinc- and calcium-binding SIOOB interacts and co-localizes with IQGAPI during dynamic rearrangement of cell membranes. I Biol Chem 2002, 277:49998-50007. Epub 2002 Oct 10

50. Roy M, Li Z, Sacks DB: IQGAPI binds ERK2 and modulates its activity. J Biol Chem 2004, 279: I7329-37. Epub 2004 Feb I7

51. Topp JD, Gray NW, Gerard RD, Horazdovsky BF: Alsin is a Rab5 and Racl guanine nucleotide exchange factor. I Biol Chem 2004, 279:246I 2-23. Epub 2004 Mar 19

52. Kunita R, Otomo A, Mizumura H, Suzuki K, Showguchi-Miyata J, Yanagisawa $Y$, Hadano S, Ikeda JE: Homo-oligomerization of ALS2 through its unique carboxy-terminal regions is essential for the ALS2-associated Rab5 guanine nucleotide exchange activity and its regulatory function on endosome trafficking. J Biol Chem 2004, 7:7.

53. Yu H, Leaf DS, Moore HP: Gene cloning and characterization of a GTP-binding Rab protein from mouse pituitary AtT-20 cells. Gene 1993, I32:273-8.

54. Lutcke A, Parton RG, Murphy C, Olkkonen VM, Dupree P, Valencia $A$, Simons K, Zerial $M$ : Cloning and subcellular localization of novel rab proteins reveals polarized and cell type-specific expression. J Cell Sci 1994, 1 07:3437-48.

55. Schafer U, Seibold S, Schneider A, Neugebauer E: Isolation and characterisation of the human rab 18 gene after stimulation of endothelial cells with histamine. FEBS Lett 2000, 466: | 48-54.

56. Segev $\mathrm{N}$ : insight into functions through novel interactions. Curr Opin Cell Biol 200I, I 3:500-I I.

57. Seabra MC, Mules EH, Hume AN: Rab GTPases, intracellular traffic and disease. Trends Mol Med 2002, 8:23-30.

58. Smith AN, Lovering RC, Futai M, Takeda J, Brown D, Karet FE: Revised nomenclature for mammalian vacuolar-type $\mathbf{H +}$. ATPase subunit genes. Mol Cell 2003, I 2:80I-3.

59. Sun-Wada GH, Yoshimizu T, Imai-Senga Y, Wada Y, Futai M: Diversity of mouse proton-translocating ATPase: presence of multiple isoforms of the C, d and $\mathbf{G}$ subunits. Gene 2003, 302: 147-53.

60. Nishi T, Forgac M: The vacuolar $(\mathbf{H +})$-ATPases-nature's most versatile proton pumps. Nat Rev Mol Cell Biol 2002, 3:94-I03.

61. Demirci FY, White NJ, Rigatti BW, Lewis KF, Gorin MB: Identification, genomic structure, and screening of the vacuolar proton-ATPase membrane sector-associated protein M8-9 gene within the CODI critical region (XpII.4). Mol Vis 200I, 7:234-9.

62. Ludwig J, Kerscher S, Brandt U, Pfeiffer K, Getlawi F, Apps DK, Schagger $\mathrm{H}$ : Identification and characterization of a novel 9.2-kDa membrane sector-associated protein of vacuolar protonATPase from chromaffin granules. I Biol Chem 1998, 273:10939-47.

63. Kornak U, BosI MR, Kubisch C: Complete genomic structure of the CLCN6 and CLCN7 putative chloride channel genes(I). Biochim Biophys Acta 1999, I 447: 100-6.

64. Campos-Xavier AB, Saraiva JM, Ribeiro LM, Munnich A, CormierDaire V: Chloride channel 7 (CLCN7) gene mutations in intermediate autosomal recessive osteopetrosis. Hum Genet 2003, I I 2: 186-9. Epub 2002 Nov 7

65. Li W, Zhang Q, Oiso N, Novak EK, Gautam R, O'Brien EP, Tinsley CL, Blake DJ, Spritz RA, Copeland NG, et al.: Hermansky-Pudlak 
syndrome type 7 (HPS-7) results from mutant dysbindin, a member of the biogenesis of lysosome-related organelles complex I (BLOC-I). Nat Genet 2003, 35:84-9. Epub 2003 Aug 17

66. Pennacchio LA, Myers RM: Isolation and characterization of the mouse cystatin B gene. Genome Res 1996, 6:1 103-9.

67. Pennacchio LA, Lehesjoki AE, Stone NE, Willour VL, Virtaneva K, Miao J, D'Amato E, Ramirez L, Faham M, Koskiniemi M, et al.: Mutations in the gene encoding cystatin B in progressive myoclonus epilepsy (EPMI). Science 1996, 27I: I73I-4.

68. Shannon P, Pennacchio LA, Houseweart MK, Minassian BA, Myers RM: Neuropathological changes in a mouse model of progressive myoclonus epilepsy: cystatin B deficiency and Unverricht-Lundborg disease. J Neuropathol Exp Neurol 2002, 61:1085-9|

69. Beccari T, Datti A, Orlacchio A, Farinelli S, Blasi E, Hoade J, Stirling JL: Calcium ionophore A-23 187 inhibits the secretion of betahexosaminidase from the GG2EE mouse macrophage cell line. Biochem Int 1992, 27:783-9|.

70. Beccari T, Hoade J, Orlacchio A, Stirling JL: Cloning and sequence analysis of a cDNA encoding the alpha-subunit of mouse beta- $\mathrm{N}$-acetylhexosaminidase and comparison with the human enzyme. Biochem J 1992, 285:593-6.

7I. Lankar D, Vincent-Schneider H, Briken V, Yokozeki T, Raposo G, Bonnerot C: Dynamics of major histocompatibility complex class II compartments during B cell receptor-mediated cell activation. J Exp Med 2002, 195:46I-72.

72. Ezaki J, Takeda-Ezaki M, Koike M, Ohsawa Y, Taka H, Mineki R, Murayama K, Uchiyama $Y$, Ueno T, Kominami E: Characterization of $\mathrm{Cln} 3 \mathrm{p}$, the gene product responsible for juvenile neuronal ceroid lipofuscinosis, as a lysosomal integral membrane glycoprotein. J Neurochem 2003, 87: 1296-308.

73. Mycko MP, Cwiklinska H, Szymanski J, Szymanska B, Kudla G, Kilianek L, Odyniec A, Brosnan CF, Selmaj KW: Inducible heat shock protein 70 promotes myelin autoantigen presentation by the HLA class II. J Immunol 2004, I72:202-I3.

74. Chae TH, Kim S, Marz KE, Hanson PI, Walsh CA: The hyh mutation uncovers roles for alpha Snap in apical protein localization and control of neural cell fate. Nat Genet 2004, 36:264-70. Epub $2004 \mathrm{Feb}$ I

75. Lemons PP, Chen D, Bernstein AM, Bennett MK, Whiteheart SW: Regulated secretion in platelets: identification of elements of the platelet exocytosis machinery. Blood 1997, 90:1490-500.

76. Walter M, Davies JP, loannou YA: Telomerase immortalization upregulates Rab9 expression and restores LDL cholesterol egress from Niemann-Pick Cl late endosomes. J Lipid Res 2003, 44:243-53. Epub 2002 Nov 4

77. Davies JP, Cotter PD, loannou YA: Cloning and mapping of human Rab7 and Rab9 cDNA sequences and identification of a Rab9 pseudogene. Genomics 1997, 41:131-4.

78. van der Stoep N, Quinten E, van den Elsen PJ: Transcriptional regulation of the MHC class II trans-activator (CIITA) promoter III: identification of a novel regulatory region in the 5'untranslated region and an important role for CAMP-responsive element binding protein $I$ and activating transcription factor-I in CIITA-promoter III transcriptional activation in B lymphocytes. J Immunol 2002, 169:506I-7I.

79. Romisch K: Surfing the Sec6I channel: bidirectional protein translocation across the ER membrane. J Cell Sci 1999, I | 2:4|85-9|.

80. Hirama T, Miller CW, Koeffler HP: Translocon-associated protein alpha transcripts are induced by granulocyte-macrophage colony-stimulating factor and exhibit complex alternative polyadenylation. FEBS Lett 1999, 455:223-7.

81. Yamagata K, Nakanishi T, Ikawa M, Yamaguchi R, Moss SB, Okabe M: Sperm from the calmegin-deficient mouse have normal abilities for binding and fusion to the egg plasma membrane. Dev Biol 2002, 250:348-57.

82. Romagnoli P, Germain RN: Inhibition of invariant chain (li)-calnexin interaction results in enhanced degradation of li but does not prevent the assembly of alpha beta li complexes. J Exp Med 1995, 182:2027-36.

83. Meyer HA, Hartmann E: The yeast SPC22/23 homolog Spc3p is essential for signal peptidase activity. J Biol Chem 1997, 272:13159-64.
84. Edgar AJ, Polak JM: Human homologues of yeast vacuolar protein sorting 29 and 35. Biochem Biophys Res Commun 2000, 277:622-30.

85. Murk JL, Humbel BM, Ziese U, Griffith JM, Posthuma G, Slot JW, Koster AJ, Verkleij AJ, Geuze HJ, Kleijmeer MJ: Endosomal compartmentalization in three dimensions: implications for membrane fusion. Proc Natl Acad Sci U S A 2003, 100:13332-7. Epub 2003 Nov 3

86. Oertle T, Klinger M, Stuermer CA, Schwab ME: A reticular rhapsody: phylogenic evolution and nomenclature of the RTN/ Nogo gene family. Faseb J 2003, 17:1238-47.

87. Kumamaru E, Kuo CH, Fujimoto T, Kohama K, Zeng LH, Taira E, Tanaka $\mathrm{H}$, Toyoda $\mathrm{T}$, Miki $\mathrm{N}$ : Reticulon 3 expression in rat optic and olfactory systems. Neurosci Lett 2004, 356:17-20.

88. Chu CC, Paul WE: Expressed genes in interleukin-4 treated B cells identified by $c D N A$ representational difference analysis. Mol Immunol 1998, 35:487-502.

89. Mootha VK, Bunkenborg J, Olsen JV, Hjerrild M, Wisniewski JR, Stahl E, Bolouri MS, Ray HN, Sihag S, Kamal M, et al.: Integrated analysis of protein composition, tissue diversity, and gene regulation in mouse mitochondria. Cell 2003, I 15:629-40.

90. Duffield A, Kamsteeg EJ, Brown AN, Pagel P, Caplan MJ: The tetraspanin CD63 enhances the internalization of the $H, K$ ATPase beta-subunit. Proc Natl Acad Sci U S A 2003, 100:15560-5. Epub 2003 Dec 5

91. Engering A, Kuhn L, Fluitsma D, Hoefsmit E, Pieters J: Differential post-translational modification of CD63 molecules during maturation of human dendritic cells. Eur J Biochem 2003, 270:24I2-20.

92. Vogt $A B$, Spindeldreher S, Kropshofer H: Clustering of MHC-peptide complexes prior to their engagement in the immunological synapse: lipid raft and tetraspan microdomains. Immunol Rev 2002, 189:|36-5I.

93. McBride K, Baron C, Picard S, Martin S, Boismenu D, Bell A, Bergeron J, Perreault C: The model B6(dom I) minor histocompatibility antigen is encoded by a mouse homolog of the yeast STT3 gene. Immunogenetics 2002, 54:562-9. Epub 2002 Oct 2

94. Waterham HR, Koster J, Romeijn GJ, Hennekam RC, Vreken P, Andersson HC, FitzPatrick DR, Kelley RI, Wanders RJ: Mutations in the 3beta-hydroxysterol Delta24-reductase gene cause desmosterolosis, an autosomal recessive disorder of cholesterol biosynthesis. Am J Hum Genet 200I, 69:685-94. Epub 200I Aug 22

95. Stremmel W, Pohl L, Ring A, Herrmann T: A new concept of cellular uptake and intracellular trafficking of long-chain fatty acids. Lipids 200I, 36:98I-9.

96. Hemmaplardh D, Morgan RG, Morgan EH: Role of plasma membrane phospholipids in the uptake and release of transferrin and its iron by reticulocytes. Membr Biol 1977, 33:195-2 I 2.

97. Collins CS, Kalish JE, Morrell JC, McCaffery JM, Gould SJ: The peroxisome biogenesis factors pex4p, pex 22p, pexIp, and pex6p act in the terminal steps of peroxisomal matrix protein import. Mol Cell Biol 2000, 20:75I6-26.

98. Yue Z, Jin S, Yang C, Levine AJ, Heintz N: Beclin I, an autophagy gene essential for early embryonic development, is a haploinsufficient tumor suppressor. Proc Natl Acad Sci U S A 2003, 100:15077-82. Epub 2003 Dec I

99. Yu L, Alva A, Su H, Dutt P, Freundt E, Welsh S, Baehrecke EH, Lenardo MJ: Regulation of an ATG7-beclin I program of autophagic cell death by caspase-8. Science 2004, 304:1500-2. Epub 2004 May 6

100. Lee CK, Smith E, Gimeno R, Gertner R, Levy DE: STATI affects lymphocyte survival and proliferation partially independent of its role downstream of IFN-gamma. J Immunol 2000, 164: $1286-92$.

10I. Kang SJ, Wang S, Kuida K, Yuan J: Distinct downstream pathways of caspase- $I I$ in regulating apoptosis and cytokine maturation during septic shock response. Cell Death Differ 2002 , 9: III5-25.

102. Schauvliege R, Vanrobaeys J, Schotte P, Beyaert R: Caspase-I I gene expression in response to lipopolysaccharide and interferongamma requires nuclear factor-kappa $B$ and signal transducer and activator of transcription (STAT) I. J Biol Chem 2002, 277:41624-30. Epub 2002 Aug 26

103. Prasad KV, Ao Z, Yoon Y, Wu MX, Rizk M, Jacquot S, Schlossman SF: CD27, a member of the tumor necrosis factor receptor fam- 
ily, induces apoptosis and binds to Siva, a proapoptotic protein. Proc Natl Acad Sci U S A 1997, 94:6346-5I.

104. Fortin A, MacLaurin JG, Arbour N, Cregan SP, Kushwaha N, Callaghan SM, Park DS, Albert PR, Slack RS: The proapoptotic gene SIVA is a direct transcriptional target for the tumor suppressors p53 and E2FI. J Biol Chem 2004, 279:28706-14. Epub 2004 Apr 22

105. Bliskovski V, Liddell R, Ramsay ES, Miller MJ, Mock BA: Structure and localization of mouse Pmscll and Pmscl2 genes. Genomics 2000, 64: 106-10.

106. Muro Y, Yamada T, Himeno M, Sugimoto K: cDNA cloning of a novel autoantigen targeted by a minor subset of anti-centromere antibodies. Clin Exp Immunol 1998, I I I:372-6.

Publish with Bio Med Central and every scientist can read your work free of charge

"BioMed Central will be the most significant development for disseminating the results of biomedical research in our lifetime. "

Sir Paul Nurse, Cancer Research UK

Your research papers will be:

- available free of charge to the entire biomedical community

- peer reviewed and published immediately upon acceptance

- cited in PubMed and archived on PubMed Central

- yours - you keep the copyright

Submit your manuscript here:

http://www.biomedcentral.com/info/publishing_adv.asp
BioMedcentral 